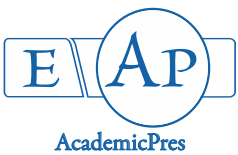

Shahrajabian MS et al. (2021)

Notulae Scientia Biologicae

Volume 13, Issue 3, Article number 11085

DOI: $10.15835 /$ nsb13311085

Review Article

\title{
Pomegranate, fruit of the desert, a functional food, and a healthy diet
}

\section{Mohamad H. SHAHRAJABIAN ${ }^{\text {la*}}$, Wenli SUN ${ }^{1 \mathrm{~b}}$, Qi CHENG ${ }^{1,2}$}

\author{
${ }^{1}$ Chinese Academy of Agricultural Sciences, Biotechnology Research Institute, Beijing 100081, China; \\ hesamshahrajabian@gmail.com (*corresponding author);sunwenli@caas.cn \\ ${ }^{2}$ Hebei Agricultural University, College of Life Sciences, Baoding, Hebei, 071000, China; Global Alliance of HeBAU-CLS\&HeQiS \\ for BioAl-Manufacturing,Baoding, Hebei071000,China; chengqi@caas.cn \\ ${ }^{a, b}$ These authors equally contributed to this paper
}

\begin{abstract}
Traditional medicinal plants contain various ranges of chemical contents and they have become popular because of effectiveness, frequently inadequate provision of modern medicine, preferences and cultural beliefs. Pomegranate belongs to the family of Punicaceae, and its various pharmacological activities are due to presence of wide range of bioactive compounds. The current searching was done by the keywords in main indexing systems including PubMed/MEDLINE, Scopus, and Institute for Scientific Web of Science as well as the search engine of Google Scholar. The keywords were traditional medicine, health benefits, pharmaceutical science, pomegranate, punicalin, punicalagin, and ellagitannins. Major polyphenols in peel and juice of pomegranate are flavonoids such as flavonols (catechin, epicatechin, gallocatechin), condensed tannins, phenolic acids such as gallic, ellagic and caffeic, hyrolysable tannins such as ellagitannins and gallotannins. The main organic acids in pomegranate juice are malic and citric, and in seed is fatty acids (punicic). The major alkaloids and lignans in peel are punigratane and isolariciresinol, respectively. Pomegranate fruit has been proven to act against various diseases like cancer, cardiovascular disorders, diabetes, AIDS, Alzheimer's disease, male infertility, inflammation, coronary heart disease, and aging. The review summarizes the beneficial impacts of pomegranate which is recommended for consumption. Pomegranate is a high potential natural functional food due to its high pharmacological activities as an ancient efficacious natural drug.
\end{abstract}

Keywords: ellagitannins; health benefits; pomegranate; punicalagin; traditional medicine

\section{Introduction}

\section{Pomegranate occurrence and classification}

Population rise, inadequate supply of drugs, prohibitive cost of treatments, side effects of several synthetic drugs and development of resistance to currently used drugs for infectious diseases have led to increased emphasis on the use of plant materials as a source of medicines (Shahrajabian et al., 2021; Sun et al., $2021 \mathrm{a}, \mathrm{b}, \mathrm{c})$. Herbal medicines proved to be the major remedy in traditional system of medicine (Shahrajabian et al., 2020a,b,c,d,e). Pomegranate (Punica granatum L.) which is a perennial fruit tree from the Punicaceae native in Iran, has been considered a functional fruit in many countries especially Iran, India, Turkey and China (Sharma et al., 2011; Soloklui et al., 2012). Its name come from the Latin name of the fruit Malum granatum, which means granular apple; and the most important producers are Iran, India, Turkey, China, the USA and

Received: 12 Feb 2021. Received in revised form: 22 Aug 2021. Accepted: 09 Sep 2021. Published online: 27 Sep 2021.

From Volume 13, Issue 1, 2021, Notulae Scientia Biologicae journal uses article numbers in place of the traditional method of continuous pagination through the volume. The journal will continue to appear quarterly, as before, with four annual numbers. 
etc (El Barnossiet al., 2021). Pomegranate has been known for hundreds of years as a healing food (Mohapatra, 2014; Tanveer et al., 2015). It has shown positive health properties due to the presence of bioactive constituents such as polyphenols, tannins and anthocyanins (Pirzadeh et al., 2020). As a functional food and nutraceutical source, pomegranate fruit quality depends on climate and growing conditions (Mirzapour and Khoshgoftarmanesh, 2013; Rahimi et al., 2017); moreover, it is also considered as an ancient medicine (Yisimayili et al., 2019). On the basis of the Bible and the Koran, pomegranate has been a symbol of fertility (Mars, 2000; Ismail et al., 2014). In Iran, it is one of the most important Iranian horticultural products, which is usually cultivated in arid and semi-arid regions (Tatari et al., 2020). The pomegranate seeds are rich in crude protein, crude lipids, dietary fiber and minerals such as K, P, Mg and Ca (Dadashi et al., 2013). In Iran, Alak was the most promising cultivar due to highest fruit size, fruit weight, and juice and least skin percentage, SourSweet, Rabab, and Black Skin cultivars showed the highest content of total anthocyanins, total phenolics, and ascorbic acid, and total soluble solid, which are suitable for fresh consumption and human health benefits (Asadi-Gharneh et al., 2017). The peal and arils of the fruits of Black Skin are being used in Persian traditional medicine (Asadi-Gharneh et al., 2017). The pomegranate has narrow and lance-shaped leaves which are glossy and leathery. The attractive scarlet, white or variegated flowers are over an inch across and have 5 to 8 crumpled petals and a red, fleshy, tubular calyx which persists on the fruit. The flowers may be solitary or grouped in twos and threes at the ends of the branches. The pomegranate is self-pollinated as well as cross-pollinated by insects. Cross-pollination increases the fruit set and wind pollination is insignificant. The wide fruit is crowned at the base by the prominent calyx, the tough, leathery skin or rind is typically yellow overlaid with light or deep pink or rich red. Its classifications are on the basis of agronomical characteristics, especially color and shape (Ozkan, 2005; Orhan et al., 2014). The cracking of mature fruit is an important physiological disorder which causes great economic loss to pomegranate. The pomegranate seed is the whole grain and constitutes the edible part of the fruit (Melgarejo et al., 2020). The peel is the main by-product after juice processing (Mphahlele et al., 2019). It has been reported that higher fruit temperature, firmness, and peel thickness decreased bruise damage to the pomegranate fruit, and both storage time and increased radius of curvature increased the bruise volume and bruise area, respectively (Shafie et al., 2015). Chinese cultivars have some unusual features such as spurtype growth habit, double flowers and white flowers (Verma et al., 2010). Seedless fruits contain soft-seeded compared to old varieties (Stover and Mercure, 2007). The aim of this article is survey and introduce the most important health benefits of pomegranate with considering its chemical constituents.

\section{Pomegranate nutritional composition and chemical constituents}

The most important known compounds of pomegranate are amino acids such as lysine, methionine, cysteine, isoleucine, leucine, phenylalanine, tyrosine, histidine, aspartic, glutamic, serine, glycine, arginie, alanine, and proline; minerals such as calcium $(\mathrm{Ca})$, magnesium $(\mathrm{Mg})$, potassium $(\mathrm{K})$, sodium $(\mathrm{Na})$, phosphorus $(\mathrm{P})$, iron $(\mathrm{Fe})$, zinc $(\mathrm{Zn})$, manganse $(\mathrm{Mn})$, copper $(\mathrm{Cu})$, and selenium $(\mathrm{Se})$; Vitamins such as thiamine (B1), riboflavin (B2), L-Ascorbic acid (C), $\alpha$-Tochoferol (E), and retinol (A); Fats such as myristic, palmitic, srearic, arachidic, behenic, stearoleic, gadoleic, erucic, ecosapentaenoic, docosatetraenoic and etc (Hasnaoui et al., 2011; Ahmad et al., 2018; Ma et al., 2019). Pomegranate's nutrient values for $100 \mathrm{~g}$ have been shown in Table 1. Nutrient content of pomegranate peel (per $100 \mathrm{~g}$ ) is presented in Table 2. 
Table 1. Pomegranate's nutrient values for $100 \mathrm{~g}$ (Ahmad et al., 2018)

\begin{tabular}{|l|c|}
\hline \multicolumn{1}{|c|}{ Composition } & Content \\
\hline Water & $77.93 \mathrm{~g}$ \\
\hline Energy & $83 \mathrm{kcal}$ \\
\hline Protein & $1.67 \mathrm{~g}$ \\
\hline Total lipid (Fat) & $1.17 \mathrm{~g}$ \\
\hline Ash & $0.53 \mathrm{~g}$ \\
\hline Carbohydrates & $18.70 \mathrm{~g}$ \\
\hline Fiber & $4.0 \mathrm{~g}$ \\
\hline Sugars & $13.67 \mathrm{~g}$ \\
\hline Calcium & $10 \mathrm{mg}$ \\
\hline Iron & $0.3 \mathrm{mg}$ \\
\hline Magnesium & $12 \mathrm{mg}$ \\
\hline Phosphorus & $36 \mathrm{mg}$ \\
\hline Potassium & $236 \mathrm{mg}$ \\
\hline Sodium & $3 \mathrm{mg}$ \\
\hline Ascorbic acid & $10.2 \mathrm{mg}$ \\
\hline Choline & $7.6 \mathrm{mg}$ \\
\hline
\end{tabular}

Table 2. Nutrient content of pomegranate peel (per $100 \mathrm{~g})$ (Ahmad et al., 2018)

\begin{tabular}{|l|c|}
\hline \multicolumn{1}{|c|}{ Composition } & Content \\
\hline Total solid & 94.50 \\
\hline Moisture & 5.40 \\
\hline Total sugars & 17.70 \\
\hline Reducing sugars & 4.34 \\
\hline Protein & 4.90 \\
\hline Crude fiber & 16.30 \\
\hline Fat content & 1.26 \\
\hline Ash & 3.40 \\
\hline
\end{tabular}

Proximate composition of pomegranate seeds is percentage moisture (8.6\%), total lipids (27.2\%), crude protein $(13.2 \%)$, crude fiber $(35.3 \%)$, pectin $(6 \%)$, total sugars $(4.2 \%)$, and ash $(2 \%)$; trace minerals present in pomegranate seeds are iron (1.3 ppm), sodium (6 ppm), magnesium (12.4 ppm), potassium (45.2 ppm), zinc (1 ppm), and copper (1.2 ppm) (Khan et al., 2017). Nutritional values of pomegranate seeds are shown in Table 3. Fatty acids found in pomegranate seeds are presented in Table 4. The name, peel color, aril color, taste and origin of 31 pomegranate cultivars in Iran are mentioned in Table 5.

Table 3. Nutritional values of pomegranate seeds (Khan et al., 2017)

\begin{tabular}{|l|c|}
\hline \multicolumn{1}{|c|}{ Compounds } & Nutritional value \\
\hline Energy & 72 calories \\
\hline Carbohydrates & 16.3 grams \\
\hline Protein & 1.5 grams \\
\hline Fat & 1 gram \\
\hline Fiber & 3.5 grams \\
\hline Sugar & 11.9 grams \\
\hline Vitamin K & 14.3 micrograms (17.9\% DV) \\
\hline Vitamin C & 8.9 milligrams (14.8\% DV) \\
\hline Foliate & 33 micrograms (8.3\% DV) \\
\hline Potassium & 205 milligrams (5.9\% DV) \\
\hline Vitamin B6 & 0.07 milligrams (3.5\% DV) \\
\hline Phosphorus & 31 milligrams (3.1\% DV) \\
\hline
\end{tabular}

Percent DV indicates daily values. 
Table 4. Fatty acids found in pomegranate seeds (Khan et al., 2017)

\begin{tabular}{|l|c|}
\hline \multicolumn{1}{|c|}{ Fatty acids } & Values (\%) \\
\hline Caproic acid & 2.16 \\
\hline Punicic acid & 65.3 \\
\hline Capric acid & 0.95 \\
\hline Lauric acid & 6.62 \\
\hline Myristic acid & 7.56 \\
\hline Myristoleic acid & 0.41 \\
\hline Palmitic acid & 4.8 \\
\hline Palmitoleic acid & 0.47 \\
\hline Stearic acid & 2.3 \\
\hline Linoleic acid & 6.6 \\
\hline Oleic acid & 5.13 \\
\hline
\end{tabular}

Table 5. The name, peel color, aril color, taste and origin of 31 pomegranate cultivars in Iran (Nemati et al., 2012)

\begin{tabular}{|c|c|c|c|c|}
\hline Cultivars & Peel color & Aril color & Taste & Origin \\
\hline $\begin{array}{l}\text { 'Shirine Dane Sefide } \\
\text { Ferdos' }\end{array}$ & Red & Red & Sweet & Khorasgan \\
\hline $\begin{array}{l}\text { 'Torsheshahvare } \\
\text { Kashmar' }\end{array}$ & Red & Red & Sour & Khorasgan \\
\hline 'Shishe Kab’ & Red & Red & Sweet-sour & Khorasgan \\
\hline 'Mazarie Bajestan' & Pink & Yellow & Sweet-sour & Khorasgan \\
\hline 'Dom Anbaroti' & White & Yellow & Sour & Khorasgan \\
\hline $\begin{array}{l}\text { 'Shirin Dane } \\
\text { Ghermeze Ferdos' }\end{array}$ & Pink & Red & Sweet & Khorasgan \\
\hline 'Khazar Bajestani' & Red & Red & Sweet-sour & Khorasgan \\
\hline 'Leili Post Nazok' & Red & Red & Sweet-sour & Khorasgan \\
\hline 'Leili Post Koloft' & Pink & Yellow & Sweet-sour & Khorasgan \\
\hline $\begin{array}{l}\text { 'Torshe Shahvare } \\
\text { Ferdos' }\end{array}$ & Red & Red & Sour & Khorasgan \\
\hline $\begin{array}{l}\text { 'Bazmanie Post } \\
\text { Nazok' }\end{array}$ & Pink & Pink & Sweet-sour & Sistan o Balochestan \\
\hline 'Savehei Post Sefid' & White & Pink & Sweet-sour & Sistan o Balochestan \\
\hline $\begin{array}{l}\text { 'Savehei Post } \\
\text { Ghermez' }\end{array}$ & Pink & Yellow & Sweet-sour & Sistan o Balochestan \\
\hline $\begin{array}{l}\text { 'Malase Porbare } \\
\text { Saravan' }\end{array}$ & Pink & Pink & Sweet-sour & Sistan o Balochestan \\
\hline $\begin{array}{l}\text { 'Malase Mamolie } \\
\text { Sarjo' }\end{array}$ & Red & Red & Sweet-sour & Sistan o Balochestan \\
\hline $\begin{array}{l}\text { 'Shekanare Post } \\
\text { Koloft' }\end{array}$ & White & Pink & Sweet & Mazandaran \\
\hline $\begin{array}{l}\text { 'Vahshie Janghalie } \\
\text { Ghaemshahr' }\end{array}$ & Red & Yellow & Sweet-sour & Mazandaran \\
\hline $\begin{array}{l}\text { 'Mahalie Parande } \\
\text { Gorgan' }\end{array}$ & White & Red & Sour & Mazandaran \\
\hline 'Post SefideDezfol' & Red & Red & Sour & Khozestan \\
\hline $\begin{array}{l}\text { 'Malase Dane Siyahe } \\
\text { Ramhormoz' }\end{array}$ & White & Red & Sweet-sour & Khozestan \\
\hline 'Malase Post Sorkh' & Red & Red & Sweet-sour & Khozestan \\
\hline
\end{tabular}


Shahrajabian MS et al. (2021). Not Sci Biol 13(3):11085

\begin{tabular}{|l|c|c|c|c|}
\hline $\begin{array}{l}\text { 'Shirine Post } \\
\text { Ghermez' }\end{array}$ & Red & Red & Sweet & Azarbaejan \\
\hline 'Shirine Post Sefid' & Pink & Pink & Sweet & Azarbaejan \\
\hline 'Malase Post Nazok' & White & Yellow & Sweet-sour & Azarbaejan \\
\hline 'Zagh Yazdi' & Red & Red & Sour & Yazd \\
\hline 'Zagh Yazdi' & Red & Red & Sweet-sour & Yazd \\
\hline 'Malase Yazdi' & Black & Yellow & Sweet & Yazd \\
\hline 'Gorje Shahvar' & Pink & Pink & Sweet & Yazd \\
\hline 'Agha Mohammadali' & Red & Red & Sweet & Markazi \\
\hline 'Alake Shirine Saveh' & Red & Red & Sweet & Markazi \\
\hline 'Malase Saveh' & Red & Red & Sweet-sour & \\
\hline
\end{tabular}

Several bioactive compounds were extracted by the pomegranate peels which can be employed for the preparation of nutraceuticals (Turrini et al., 2019). Around 153 different phytochemicals have been found in pomegranate which have ability to fight against various diseases (Karimi et al., 2017). Its fruit peel contains phenolic compounds including ellagic acid, ellagitannins, lignins, catechin, rutin, punicalagin and epicatechin (Fischer et al., 2011; Glazer et al., 2012; Rosas-Burgos et al., 2017), and the peel consists of cellulose, ligning, pectin and proteins (Hasnaoui et al., 2014; Abid et al., 2017). Rowayshed et al. (2013) also reported catechins, phenol gallic acid, caffeic acid, ellagic acid, p-coumaric acid and resocenol compounds in pomegranate peels powder. Peels and membranes of pomegranate fruits can be recommended as a source of highly and lowly methyl-esterified pectic polysaccharides (Shakhmatov et al., 2019). The most abundant compounds in pomegranate in Mexico were hexanol, (Z)-3-hexen-1-ol, hexanal, 4-terpineol, $\alpha$-terpineol, and 2-ethyl-1hexanol, and in the peel, high concentration of color, phenols, flavonoids, and antioxidants were observed (Escarcega et al., 2020). Pomegranate exerts antiproliferative, anti-invasive and antimetastatic effects, induces apoptosis through modulation of $\mathrm{Bcl}-2$ proteins, increases $\mathrm{p} 21$ and $\mathrm{p} 27$, and downregulates cyclin-cdk network (Faria and Calhau, 2011). Pomegranate seed oil is a rich source of rare conjugated fatty acids (punicic acid) (Paul et al., 2020). Ellagic acid (EA) is one of the most important biological molecules found in pomegranate which may induce vasorelaxation, oxygen free radical scavenging, hypolipidemic, anti-inflammatory and anticarcinogenic activities (Usta et al., 2013). Pomegranates have the potential to cause toxicity to ruminants, because large amounts of toxic gallic acid can potentially be produced through rumen fermentation of punicalagin (Read et al., 2019). Concentrated pomegranate peel extract supplementation increases milk antioxidant capacity which have higher benefits in individuals with lower natural productivity capacity (ArgovArgaman et al., 2020). Pomegranate juice powder can replace some or all sucrose in fermentation matrix for the production of functional yogurt ( $\operatorname{Pan}$ et al., 2019). There are 11 volatile organic compounds namely 1 hexanol, [Z]-3-hexen-1-ol, 1-octanol, $\alpha$-terpineol, $\beta$-myrcene, limonene, [E]- $\alpha$-bergamotene, $\beta$-caryophyllene, hexanal, [E]-2-hexenel, and guaiacol are common to pomegranate juices and seeds; hexalin, phenylacetaldehyde, 3-methyl butanal, and methyl-(1-methylethenyl) benzene are found just in seeds (Guler and Gul, 2017). Pomegranate juices has similar or higher sweetness than apple, orange and sour cherry juice (Topalovic et al., 2020). The fruit quality of pomegranate is a balance between taste attributes and nutraceutical compounds (Tozzi et al., 2020). It contains significant amounts of phenolic ingredients, and the antioxidant and anti-inflammatory impacts of pomegranate poly phenols have been confirmed previously (Yan et al., 2017; Pontonio et al., 2019; Morvaridzadeh et al., 2020). Pomegranate peel polysaccharides (PPP) is a good source for dietary supplement application, which has good antioxidant activity in vivo (Wu et al., 2019). A positive correlation between antioxidant activity and total phenolic content was reported (Derakhshanet al., 2018). The reason of the bright color of pomegranate flowers is a type of the flavonoids, which is anthocyanins (Zhang et al., 2011; Ben-Simhon et al., 2015). The pomegranate peel polysaccharides are composed of rhamnose, glucuronic acid, galacturonic acid, glucose and xylose in the molar percentage of $0.71 \%, 27.07 \%, 22.05 \%$, 22.12\%, and 28.05\%, respectively (Wu et al., 2019). Habibnia et al. (2012) found that the predominant fatty acids in Iranian pomegranate was punicic acid, and beta-sitosterol and $\gamma$-tochopherol were the main sterol and 
tochopherol present in the extracted oil, respectively. The pomegranate peel, seed and whole fruit powder consists of moisture content, ash, protein, crude fiber, fat and minerals such as sodium, calcium, magnesium, potassium, phosphorus and iron (Sharma et al., 2018). Pomegranate seed oil (PSO) nanoemulsion is widely used as a promising delivery system for $\alpha$-tocopherol (Sahafi et al., 2021). Pomegranate ellagitannins may inhibit $\alpha$-flucosidase activity in vitro possibly affecting in vivo starch digestion (Bellesia et al., 2015). Its juice could be beneficial as a dietary supplement in patients receiving chemotherapy medications (Bakir et al., 2015). The polyphenols are useful indicators to differentiate the geographical localities of pomegranate peel which can be used to predict their antioxidant activities (Kam et al., 2013). Pomegranate flower consist of triterpenoids, asiatic acid and ursolic acid; pomegranate juice consists of catechin, ascorbic acid, iron, glucose and amino acids; pomegranate leaves consist of flavones, tannins, luteolin and glycosides; pomegranate seed oil consists of sterols, ellagic acid, 95\% punicic acid and fatty acids; pomegranate root and bark consist of piperidine alkaloids, ellagitannins and punicalin; and pomegranate rind consists of flavonols, quercetin rutin and fatty acids (Huang et al., 2005; Lan et al., 2009). Principle constituents of pomegranate root and bark are ellagitannins, piperidine alkaloids, pyrrolidine alkaloid and pelletierine alkaloids (Neuhofer et al., 1993; Gil et al., 2000). The most important constituents of pomegranate leaves are carbohydrates, reducing sugars, sterols, saponins, flavanoids, tannins, piperidine alkaloids, flavones, glycoside and ellagitannins (Nawwar et al., 1994; Chaitra et al., 2012). Lignins, sterols and terpenoids are the most important active phytochemicals in seed, bark and leaves (Lansky and Newman, 2007), alkaloids in bark and leaves, and fatty acids and triglycerides in seed oil (Lansky and Newman, 2007). Simple gallyol derivatives and organic acids have been reported in leaves and juice, respectively (Ender et al., 2002). Flavonols is one of the main phytochemicals in rind, fruit (Mirdehghan and Rahemi, 2007), and bark and leaves (Lansky and Newman, 2007; Jaiswal et al., 2010). Anthocyanins and anthocyanidins, catechin and procyanidins have been found in juice and rind (Jasiwal et al., 2010), estrogens in seeds and peel extracts (Kho et al., 2010), and essential oils in seeds (Abbasi et al., 2008). Name of different compounds along with their parts are shown in Table 6. Nozohour et al. (2018) reported that the main phytochemicals identified in the ethanolic extracts of the pomegranate peel and seed are furfural, heptacosane, 5-hydroxymethylfurfural, ellagic acid, ellagic acid, 3,3'-di-O-methyl, ellagic aci, 3,3',4'-tri-Omethyl, punicalagin, pyrogallol, gallic acid, catechin, epicatechin, gallocatechin, gallocatechin-(4,8)-catechin, ascorbic acid, linoleic acid, stigmasterol, and gamma-sitosterol (Tanaka et al., 1986; Schubert et al., 1999; Amakura et al., 2000; Hornung et al., 2002; Wang et al., 2004; Nozohour et al., 2018).

Table 6. Name of different compounds along with their parts (Ahmad et al., 2018)

\begin{tabular}{|c|c|}
\hline Pomegranate part & Chemical compounds \\
\hline Peels & $\begin{array}{l}\text { Gallic acid, Ellagic acid, Punicalin, Punicalagin, Caffeic acid, Ellagitannins, } \\
\text { Pelletierine, alkaloids, Luteolin, Kaempferol, Quercetin }\end{array}$ \\
\hline Seeds & $\begin{array}{l}\text { 3,3-Di- } O \text {-methylellagic acid, 3,3,4-Tri- } O \text {-methylellagic acid, Punicic acid, Pleic } \\
\text { acid, Palmitic acid, Stearic acid, Linoleic acid, Sterols, Tocopherols, Sex steroids }\end{array}$ \\
\hline Juice & $\begin{array}{c}\text { Simple sugars, Aliphatic organic acids, Gallic acid, Ellagic acid, Quinic acid, } \\
\text { Flavonols, Amino acids, Minerals, EGCG, Ascorbic acid }\end{array}$ \\
\hline Leaves & $\begin{array}{c}\text { Carbohydrates, Reducing sugars, Sterols, Saponins, Flavanoids, Tannins, } \\
\text { Piperidine alkaloids, Flavone, Glycoside, Ellagitannins }\end{array}$ \\
\hline Root and Bark & $\begin{array}{c}\text { Ellagitannins, Piperidine alkaloids, Pyrrolidine alkaloid, } \\
\text { Pelletierine alkaloids }\end{array}$ \\
\hline Flower & $\begin{array}{l}\text { Gallic acids, Ursolic acid, Triterpenoids, } \\
\text { Fatty acids }\end{array}$ \\
\hline
\end{tabular}




\section{Potential Pharmaceutical and Health Benefits of Pomegranate in Traditional Medicine and Modern Medicine Industry}

In traditional medicine, it may helpful for treating diseases such as ordinary diarrhea, dysentery, and stomach disorders (Lansky et al., 2000), and tannin content of pomegranate seed is usually used to treat women vaginal discharge and wound healing (Amin, 1991). The effect of pomegranate on different types of cancer such as bladder cancer (Lee et al., 2013), breast cancer (Adams et al., 2010; Sturgeon and Ronnenberg, 2010), colon cancer (Kohno et al., 2004; Waly et al., 2014), leukemia (Joseph et al., 2012), liver cancer (El-Ashmawy et al., 2016; Song et al., 2016), lung cancer (Khan et al., 2007), prostate cancer (Lucci et al., 2015; Deng et al., 2017), skin cancer (Afaq et al., 2010; George et al., 2011) have been reported. It has reported that pomegranate juice has the highest antioxidant activity among all various food types (Guo et al., 2003). Pomegranate juice powder (PJP) rich in phenolic compounds was used as some or all sucrose in the fermentation matrix for the preparation of set yogurts (Pan et al., 2019). It has been reported in many researches that polyphenols present in pomegranate imparts significant anti-inflammatory and anti-oxidant properties for prevention of various diseases (Guo et al., 2003; Lee et al., 2010). Sharma et al. (2017) reported that pomegranate has stronger antioxidant activity compared to $\beta$-carotene, ascorbic acid and vitamin $\mathrm{E}$ than green tea, and also can affect pathways involved in cancer development like cellular transformation and angiogenesis (Khan et al., 2008). The dietary supplementation with 200 and $300 \mathrm{mg} / \mathrm{kg}$ pomegranate peel extract (PPE) may increase the antioxidant potential and quality indices of broilers breast meat, and the antioxidant potential of PPE was equal to that of $\alpha$-Toc in refrigerated meat (Saleh et al., 2017). The potentiated virucidal activity of pomegranate rind extract (PRE) by co-administered zinc (II) has potential as a multi-action novel topical therapeutics against Herpes simplex virus (HSV) infections, like as cold sores (Houston et al., 2017). The usage of pomegranate extracts orally at the dose of $1500 \mathrm{mg} / \mathrm{kg}$ showed the potential of increasing sexual behavior in rats (Katana et al., 2019). The pomegranate peel is a promising feedstock for second generation ethanol production (Demiray et al., 2018). On the basis of one study, $2 \mathrm{~g} / \mathrm{kg}$ supplementation of pomegranate peel powder meal may improve the water binding capacity of broiler breast meat because of reduced cooking loss of the meat (Akuru et al., 2020). Pomegranate peel and seed methanolic extracts have notable total flavonoid and phenolic contents and also antioxidant activity, which can protect the liver against histo-pathological and some enzymatic changes induced by the Methotrexate (MTX) in rats (Doostan et al., 2019). Pomegranate peel extract was capable to boost the functional characteristics of chitosan/gelatin-based materials enhancing the desired properties for their potential application as food coatings (Bertolo et al., 2020). Pomegranate molasses has anti-inflammatory (Lee et al., 2010), antidiabetic properties (Xu et al., 2009), and important role to reduce the risk of cardiovascular diseases (El Darra et al., 2017). Ridzwanet al. (2020) reported the potency of pomegranate extract as a non-opioid substitution therapy for both in-vitro and in-vivo studies; in-vitro studies showed using of pomegranate extract treatment may be effective in decreasing the $\mu$-opioid receptor (MORs) and cyclic adenosine monophosphate (cAMP) protein levels in U-87 cells at a concentration of $0.125 \mathrm{mg} / \mathrm{mL}$. Pomegranate peel extract consumption in diabetes mellitus type 2 subject may have favourable impacts on some metabolic parameters, blood pressure, lipid profile and plasma lipid fatty acids composition (Grabez et al., 2020). Pomegranate peel extract can be used as alternative therapy for blastocystosis and for improving novel anti-Blastocystis drugs (Abdel-Hafeez et al., 2016). Pomegranate juice shows microbicidal properties for both oral hygiene and chemo-preventive in immune deficiency and cardiovascular diseases (Faria and Calhau, 2011), with tremendous anti-atherogenic and anti-anti-atherosclerotic characteristics for decreasing high blood pressure and density lipoprotein oxidation (Turk et al., 2008).

Rashidi et al. (2013) reported that concentrated pomegranate juice consumption was not effective on blood glucose and lipid profiles concentrations in type 2 diabetic patients. Pomegranate seed oil demonstrated and important therapeutic effect in the treatment of ovarian ischemia and reperfusion injury (Yayla et al., 2018). Pomegranate juice can be recommended as a suitable transport medium for avulsed teeth, and $1 \%$ of its juice was as effective as Hank's balanced salt (HBS) for maintaining PDL cell viability (Tavassoli-Hojjati et al., 
2014). Pomegranate seed extract exhibited therapeutic potential for avoidance memories, because it is a potent phytoestrogenic and antioxidant which may have compensating effects for peripheral estrogen deficit (Sarkaki et al., 2015). Black pomegranate peel extract could effectively suppress angiogenesis potentially through a vascular endothelial growth factor (VEGF) dependent mechanism (Dana et al., 2015). Natural pomegranate juice is also a potent inflammatory, and anti-thrombocytopenia treatment among elderly population (Achraf et al., 2018). Saleh et al. (2018) reported that the antioxidant potential of pomegranate pomace extract supplementation was equal to that of $\alpha$-tocopherol acetate in refrigerated meat. Martinez et al. (2019) concluded that natural extracts from pomegranate, rosemary, and hydroxytyrosol delayed the lipid oxidation, and addition of it to fish products contributed to extend the shelf life to fish. The whole fruit extract of pomegranate has cardioprotective effect against Dox-induced cardiotoxicity in rats (HassanpourFardet al., 2011). Pomegranate peel extract was found to have strong anti-inflamatory activity by the reduction in the levels of Interlukin-6 (IL-6) and tumor Necrosis Factor- $\alpha$ (TNF-alfa), and rich in phenolic and flavonoids which may enhance its reducing activity and free radical scavenging ability (Qabaha et al., 2019).

Pomegranate juice has the potential as a nutraceutical to improve health span and lifespan in human beings (Balasubramani et al., 2014). The pomegranate vinegar may prevent a high-fat diet (HFD)-induced obesity and obesity-related cardiac complications because of anti-inflammatory and anti-adiposity properties of vinegar (Bounihi et al., 2017). Under accelerated oxidation conditions, pomegranate peel metahanolic extract have the potential capability to improve the shelf life of edible oils in comparison with the most powerful synthetic antioxidant [tert-butyl hydroquinone (TBHQ)-200 ppm)] (El-Hadary and Taha, 2020). The pomegranate peel extract can be used in the treatment of oral candidiasis with no negative effects following administration in the rats (Bassiri-Jshromi et al., 2018). Pomegranate seed oil (PSO) clearly attenuate hexachlorobutadiene (HCBD)-induced nephrotoxicity (Bouroshaki et al., 2010). A decrease in hematotoxic and genotoxic effects induced by pomegranate peel is due to its powerful antioxidant capacity (Elwejet al., 2016). The fruits of some pomegranate genotypes could be used to obtain extracts very rich in punicalagins and that these substances could be used as an alternative to synthetic products to control plant disease and improve the quality of the plant products, avoiding the impact of synthetic chemicals on the environment (Rongai et al., 2019). The pomegranate peel extract showed anti-herpes simplex virus-1 (HSV) activity, probably by inhibiting the adsorption stage with SI value of 7.7 (Moradi et al., 2015). Pomegranate peel pectin can act as an effective emulsifier, and can be used as a novel polysaccharide emulsifier in the food industry (Yang et al., 2018). The antimetastatic effect of pomegranate may be attributed to molecular changes of the extracellular matrix (Ahmadiankia, 2019). The most notable pharmaceutical benefits of pomegranate have been shown in Table 7 .

Table 7. Pharmaceutical benefits of pomegranate

\begin{tabular}{|l|c|c|}
\hline Health benefits & Mechanisms and impacts & Reference \\
\hline \multirow{5}{*}{ Acute Pancreatitis } & $\begin{array}{c}\text { The higher doses of three fractions }(250 \text { and } \\
500 \mathrm{mg} / \mathrm{kg} \text { for pomegranate freeze-dried } \\
\text { power and pomegranate seeds extract and } \\
\text { doses of } 100,200 \mu \mathrm{L} / \mathrm{kg} \text { for pomegranate seed } \\
\text { oil fraction) significantly reduced amylase and } \\
\text { lipase activity in serum, pancreatic pancreatic } \\
\text { myeloperoxidase activity, edema, leukocyte } \\
\text { infiltration and vacuolization in comparison to } \\
\text { the control group. }\end{array}$ & Minaiyan et al. (2014) \\
\hline Alzheimer & $\begin{array}{c}\text { Pomegranate extract is more efficacious as a } \\
\text { protectant than a therapeutic measure in } \\
\text { reducing histopathological hallmarks in } \\
\text { Alzheimer's disease. }\end{array}$ & Almuhayawi et al. (2020) \\
\hline Anti-depressant effects & The aqueous extract of pomegranate (AE-PG) \\
& $\begin{array}{c}\text { administered by intraperitoneal route induced } \\
\text { anti-depressant like effects, and the mechanism } \\
\text { of action involved the activation of the } \\
\text { Estrogen receptor } \beta \text { (ER } \beta \text { ) and the }\end{array}$ & Valdes-Sustaita et al. (2021) \\
\hline
\end{tabular}


Shahrajabian MS et al. (2021). Not Sci Biol 13(3):11085

\begin{tabular}{|c|c|c|}
\hline & serotonergic system. & \\
\hline \multirow{4}{*}{ Anti-diabetes effects } & $\begin{array}{l}\text { a. Pomegranate seed oil (PSO) has a protective } \\
\text { effect against diabetes complications in rats, } \\
\text { and also significantly reversed streptozotocin } \\
\text { (STZ)-induced depletion in thiol content and } \\
\text { histological abnormality. }\end{array}$ & Mollazadeh et al. (2016) \\
\hline & $\begin{array}{c}\text { b. No significant impacts of pomegranate } \\
\text { supplementation on metabolic parameters in } \\
\text { patients with type } 2 \text { diabetes mellitus (T2DM) } \\
\text { was found. }\end{array}$ & Jandari et al. (2020) \\
\hline & $\begin{array}{l}\text { c. Pomegranate juice consumption as an } \\
\text { antioxidant may have a contribution in } \\
\text { changing fasting blood sugar, lipid profiles, } \\
\text { lipoprotein oxidation and human serum } \\
\text { paraoxonase (PON1) activity. }\end{array}$ & Parsaeyan et al. (2012) \\
\hline & $\begin{array}{l}\text { d. Consumption of } 2000 \mathrm{mg} \text { pomegranate seed } \\
\text { oil (PSO) per day for } 8 \text { weeks had no impact } \\
\text { on fasting blood sugar (FBS), insulin resistance } \\
\text { and lipid profile in diabetic patients. }\end{array}$ & Faghihimani et al. (2016) \\
\hline \multirow{2}{*}{ Anti-diarrheal activity } & $\begin{array}{l}\text { a. Its extract showed a concentration- } \\
\text { dependent inhibition of the spontaneous } \\
\text { movement of the isolated rat ileum and } \\
\text { attenuated acetylcholine-induced contractions. }\end{array}$ & Qnais et al. (2007) \\
\hline & $\begin{array}{l}\text { b. Its extract also caused a dose-dependent } \\
\text { decrease of gastrointestinal transit and } \\
\text { significantly protected rats against castor oi- } \\
\text { induced diarrhea enteropooling. }\end{array}$ & Qnais et al. (20070 \\
\hline \multirow{7}{*}{ Anti-cancer activity } & $\begin{array}{l}\text { a. Pomegranate extracts inhibit the growth of } \\
\text { breast, prostate, colon and lung cancer cells in } \\
\text { culture. } \\
\text { Polyphenols from pomegranate has been used } \\
\text { for prevention of prostate cancer. }\end{array}$ & $\begin{array}{c}\text { Adhami and Mukhtar (2006) } \\
\text { Adhami et al. }(2009) \\
\text { Nallanthighal et al. (2016) } \\
\text { Boggula and Peddapalli (2017) }\end{array}$ \\
\hline & $\begin{array}{l}\text { b. The extracts derived from pomegranates had } \\
\text { significant concentration-dependent } \\
\text { antiproliferative and pro-apoptotic effects } \\
\text { against MCF-7 (ER+) and MD-MBA-231 or } \\
\text { MD-MBA-435 (ER-) breast cancer cell lines. }\end{array}$ & Mehta and Lansky (2004) \\
\hline & $\begin{array}{l}\text { c. Pomegranate extract suppresses the } \\
\text { melanocyte and melanin synthesis through } \\
\text { inhibiting tyrosinase activity which is } \\
\text { important in treatment of skin cancer. }\end{array}$ & Yoshimura et al. (2005) \\
\hline & $\begin{array}{l}\text { d. The photo chemo preventive effects of } \\
\text { pomegranate against UVA and UVB } \\
\text { irradiations in normal human epidermal } \\
\text { keratinocytes (NHEK) as a test system has } \\
\text { been proved. }\end{array}$ & Syed et al. (2006) \\
\hline & $\begin{array}{l}\text { e. Pomegranate fruit extracts (PFE) dose- } \\
\text { dependently inhibited NF- } \kappa \mathrm{B} \text {-dependent } \\
\text { reporter gene expression associated with } \\
\text { proliferation invasion, and motility in } \\
\text { aggressive breast cancer phenotypes while } \\
\text { decreasing RhoC and RhoA protein } \\
\text { expression. }\end{array}$ & Khan et al. (2009) \\
\hline & $\begin{array}{l}\text { f. Pomegranate juice gains lots of attractions } \\
\text { due to its remedial and preventative roles } \\
\text { against prostate cancer because of its ability in } \\
\text { inhibiting cell growth and inducing apoptosis. }\end{array}$ & Koyama et al. (2010) \\
\hline & $\begin{array}{l}\text { g. Pomegranate extract decreased the } \\
\text { expressions of genes of the enzyme involved in } \\
\text { the synthesizing androgen and at the same } \\
\text { time downregulate the hypoxia-inducible } \\
\text { factor } 1-\alpha(\text { HIF- } 1 \alpha) \text { to constrain angiogenesis } \\
\text { in prostate cancer. }\end{array}$ & Sartippour et al. (2008) \\
\hline
\end{tabular}




\begin{tabular}{|c|c|c|}
\hline & $\begin{array}{l}\mathrm{h} \text {. The inhibitory effects of pomegranate juice } \\
\text { on progression of prostate cancer as well as its } \\
\text { role on increasing adhesion and decreasing } \\
\text { migration of the live cells has been confirmed. }\end{array}$ & Wang et al. (2012) \\
\hline & $\begin{array}{l}\text { i. Pomegranate extract suppresses cancer stem } \\
\text { cells characteristics in part due to inhibition of } \\
\text { epithelial-to-mesenchymal which can be } \\
\text { exploited in the prevention of breast cancer. }\end{array}$ & Nallanthighal et al. (2017) \\
\hline & $\begin{array}{l}\text { j. Ellagic acid induced a greater effect than } \\
\text { luteolin, suggesting that ellagic acid might be a } \\
\text { promising candidate for further preclinical } \\
\text { testing for treatment of human ovarian cancer. }\end{array}$ & Liu et al. (2017) \\
\hline & $\begin{array}{l}\text { k. Black peel pomegranate is a worthy bio- } \\
\text { agent in silver nanoparticle biosynthesis and } \\
\text { treatment of cancer. }\end{array}$ & Khorrami et al. (2019) \\
\hline & $\begin{array}{l}\text { 1. The MTT assay showed } 94.53 \% \text { inhibition } \\
\text { on the oral cancer cell lines and clonogenic } \\
\text { assay showed decrease in the colonies after } \\
\text { treating with the peel extract. }\end{array}$ & Jesse Joel et al. (2019) \\
\hline & $\begin{array}{l}\text { m. Pomegranate juice possesses a promising } \\
\text { inhibitory effect on bladder cancer (BC) } \\
\text { development, probably due to its anti-oxidant } \\
\text { and anti-inflammatory properties. It can } \\
\text { correct the expression of pro-inflammatory } \\
\text { cytokines (interleukin } 6 \text { and hypoxia-inducible } \\
\text { factor 1), it also press angiogenesis by down- } \\
\text { regulation of hypoxia-inducible factor and } \\
\text { supports apoptosis through reduction of the } \\
\text { tumor suppressor gene p } 53 \text {. }\end{array}$ & Mortada et al. (2020) \\
\hline & $\begin{array}{l}\text { n. Dwarf pomegranate extracts showed potent } \\
\text { growth inhibitory activities in human prostate } \\
\text { cancer cells (DU145), which appear to be } \\
\text { mediated by a pro-apoptotic mechanism. }\end{array}$ & Amri et al. (2020) \\
\hline & $\begin{array}{l}\text { o. Nano-pomegranates have great potential in } \\
\text { anti-breast cancer treatment, because MCF-7 } \\
\text { cells have shown remarkable efficiencies of } \\
\text { enhancing cellular uptake, inhibition and } \\
\text { necrosis and apoptosis at in vivo rat } \\
\text { experiments. }\end{array}$ & Wang et al. (2020) \\
\hline & $\begin{array}{l}\text { p. The pomegranate fruit fleshy pericarp acts as } \\
\text { a natural agent to synthesize silver } \\
\text { nanoparticles (AgNPs) which can be } \\
\text { considered as an anticancer agent. }\end{array}$ & Govindappa et al. (2021) \\
\hline & $\begin{array}{l}\text { q. Pomegranate extract and tangeretin may be } \\
\text { effective in preventing breast cancer } \\
\text { development. }\end{array}$ & Gul et al. (2021) \\
\hline \multirow{4}{*}{ Anti-inflammatory and analgesic effect } & $\begin{array}{l}\text { a. The methanol extract Amrouz (MoEA) and } \\
\text { methanol extract Sefri (MoES) have both } \\
\text { analgesic and anti-inflammatory properties. }\end{array}$ & Ouachrif et al. (2012) \\
\hline & $\begin{array}{l}\text { b. Pomegranate juice may have an anti- } \\
\text { inflammatory effect in patients with type } 2 \\
\text { diabetes (T2D), because it may reduce } \\
\text { interlukin-6 and hs-CRP concentrations in } \\
\text { plasma. }\end{array}$ & Sohrab et al. (2014) \\
\hline & $\begin{array}{l}\text { c. The phosphorylation of ERK } 1 / 2, \mathrm{p} 38, \mathrm{JNK} \\
\text { and translocation of the NF-B p } 65 \text { subunit } \\
\text { into nuclei were inhibited by the pomegranate } \\
\text { flower ethanol (PFE) treatment, and PFE } \\
\text { produced potential anti-inflammatory effect. }\end{array}$ & Xu et al. (2017) \\
\hline & $\begin{array}{l}\text { d. Pomegranate peel extracts is a promising } \\
\text { food supplement for dairy cattle, especially } \\
\text { around calving, when the animals are more } \\
\text { subject to oxidative stress and inflammatory } \\
\text { diseases. } \\
\text { Pomegranate supplementation significantly }\end{array}$ & $\begin{array}{l}\text { Taheri Rouhi et al. (2017) } \\
\text { Mastrogiovanni et al. (2020) } \\
\text { Morvaridzadeh et al. (2020) } \\
\text { Wang et al. (2020) }\end{array}$ \\
\hline
\end{tabular}




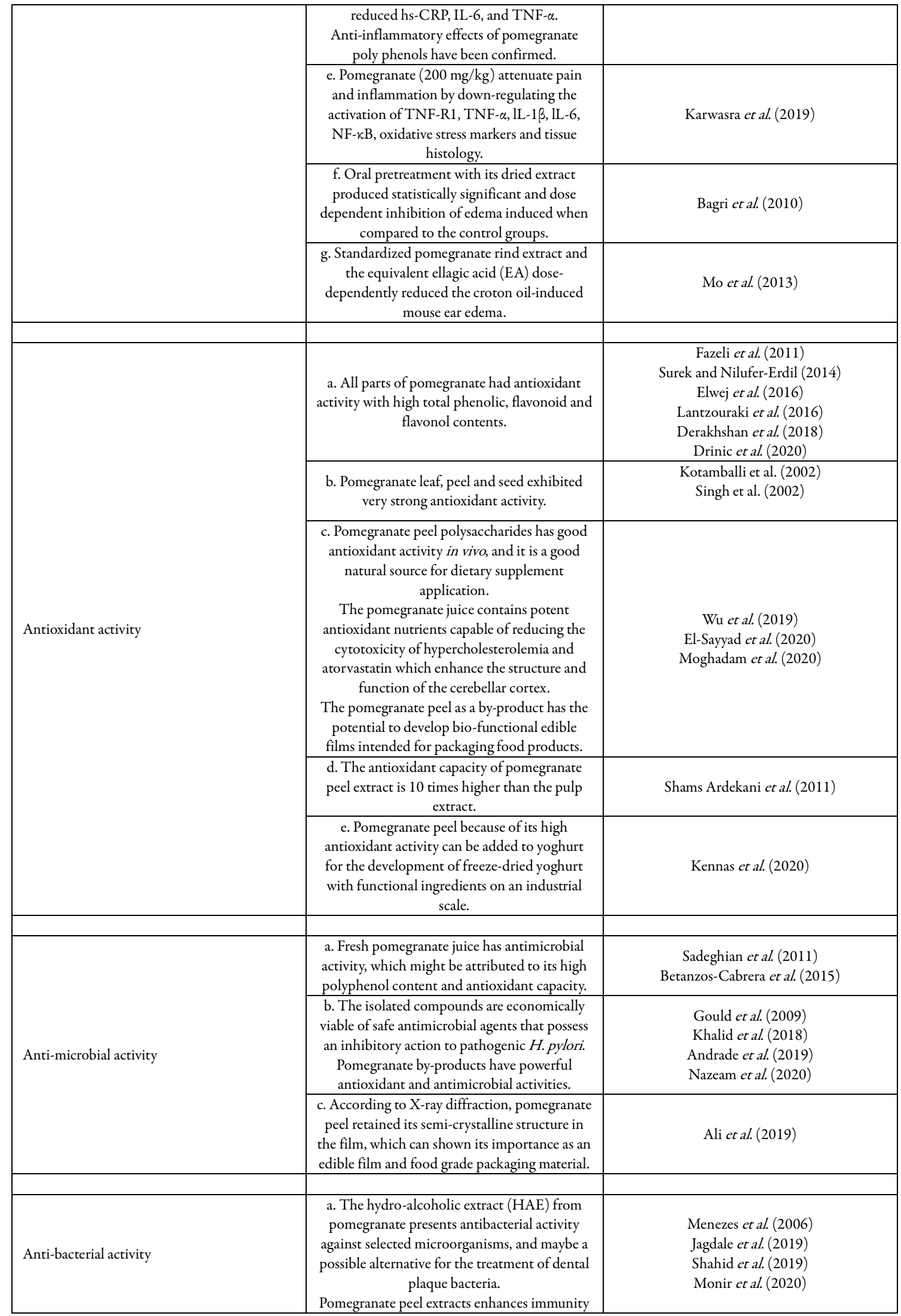




\begin{tabular}{|c|c|c|}
\hline & $\begin{array}{l}\text { and increased the protection against } \\
\text { pathogenic bacteria. }\end{array}$ & \\
\hline & $\begin{array}{l}\text { b. The total phenolic and flavonoid content of } \\
\text { pomegranate has positively associated with the } \\
\text { antibacterial activities of the fractions with } \\
\text { chloroform extract exhibiting lowest } \\
\text { antibacterial activity against Escherichiacoli } \\
\text { (MIC } 25 \mathrm{mg} / \mathrm{ml} \text { ), and the methanol fraction } \\
\text { exhibiting the highest antibacterial effect } \\
\text { against Staphylococcusaureus (MIC } 0.19 \\
\mathrm{mg} / \mathrm{ml} \text { ). }\end{array}$ & Mahboubi et al. (2015) \\
\hline & $\begin{array}{c}\text { c. The pomegranate peel extracts showed } \\
\text { antibacterial activities against } \\
\text { Pseudomonasaeruginosa and } \\
\text { Staphylococcusaureus. }\end{array}$ & Nozohour et al. (2018) \\
\hline & $\begin{array}{l}\text { d. Because of its antibacterial effects, } \\
\text { pomegranate peel is a potential source of } \\
\text { natural preservatives for the control of } \\
\text { Cronobactersakazakii in food. }\end{array}$ & Yemis et al. (2019) \\
\hline Anti-aging activity & $\begin{array}{l}\text { Pomegranate anthocyanins could be used as a } \\
\text { safe, stable, homogeneous, nonirritant and } \\
\text { effective topical anti-aging drug formulation } \\
\text { for aged people. }\end{array}$ & Abdellatif et al. (2020) \\
\hline Anti-apoptotic activity & $\begin{array}{c}\text { The methanolic extract of pomegranate peel } \\
\text { has beneficial influences and could be able to } \\
\text { inhibit Al-induced oxidative stress and } \\
\text { histopathological alterations in liver and } \\
\text { kidney of female rats. }\end{array}$ & Abdel Moneim et al. (2013) \\
\hline \multirow{2}{*}{ Anti-bacterial effects } & $\begin{array}{l}\text { a. All pomegranate extracts contain high levels } \\
\text { of phenolics and exhibited antibacterial } \\
\text { activity against Bacillus subtilis, } \\
\text { Staphylococcus aureus, Escherichiacoli and } \\
\text { Salmonella typhimurium. }\end{array}$ & Nuamsetti et al. (2012) \\
\hline & $\begin{array}{l}\text { b. Pomegranate peel extract contains bioactive } \\
\text { compounds which mitigate the deleterious } \\
\text { impacts of an in vivo infection with the model } \\
\text { enteropathogenic bacteria Citrobacter } \\
\text { rodentium (Cr). }\end{array}$ & Smith et al. (2020) \\
\hline Anti-angiogenic effects & $\begin{array}{l}\text { Pomegranate peel extract (PPE) showed anti- } \\
\text { angiogenic effects and it could be mediated in } \\
\text { part through peroxisome proliferator-activated } \\
\text { receptors (PPARs) dependent pathway. }\end{array}$ & Dana et al. (2016) \\
\hline Anti-hepatotoxic effects & $\begin{array}{l}\text { The hepatoprotective potential of the acetone } \\
\text { extract of Punica granatum fruits on tissue } \\
\text { defense systems during isoniazid- and } \\
\text { rifampicin induced hepatotoxicity in rats was } \\
\text { found. }\end{array}$ & Yogeeta et al. (2007) \\
\hline Nausea and vomiting & $\begin{array}{c}\text { Pomegranate seems to be more effective than } \\
\text { vitamin B6 in the treatment of Nausea and } \\
\text { vomiting pregnancy (NVP). }\end{array}$ & Abdolhosseini et al. (2017) \\
\hline \multirow[t]{2}{*}{$\begin{array}{l}\text { Natural preservative and anti-atherogenic } \\
\text { supplementation }\end{array}$} & $\begin{array}{l}\text { a. Polyphenolic fraction of pomegranate juice } \\
\text { can act as antiatherogenic supplementation } \\
\text { and natural preservative for meat and fatty } \\
\text { foods through direct inhibition of LDL } \\
\text { oxidation. }\end{array}$ & Faisi et al. (2018) \\
\hline & $\begin{array}{l}\text { b. The pomegranate peel phenolics may } \\
\text { improve stored meat products quality, such as } \\
\text { instrumental color retaining, limitation of }\end{array}$ & $\begin{array}{l}\text { Derakhshan et al. (2018) } \\
\text { He et al. }(2019) \\
\text { Smaoui et al. (2019) } \\
\end{array}$ \\
\hline
\end{tabular}


Shahrajabian MS et al. (2021). Not Sci Biol 13(3):11085

\begin{tabular}{|c|c|c|}
\hline & $\begin{array}{l}\text { microflora growth, retardation of lipid and } \\
\text { protein oxidation. }\end{array}$ & \\
\hline \multirow[t]{2}{*}{ Nephroprotective effects } & $\begin{array}{l}\text { a. The prophylactic consumption of } \\
\text { pomegranate juice for } 14 \text { days could show } \\
\text { nephroprotective effects by reducing oxidative } \\
\text { stress and potassium depletion. }\end{array}$ & Alimoradian et al. (2017) \\
\hline & $\begin{array}{l}\text { b. Pomegranate juice may lead to the } \\
\text { stabilization of kidney function despite using } \\
\text { captopril and gentamicin. }\end{array}$ & Alimoradian et al. (2017) \\
\hline \multirow{4}{*}{ Skin health } & $\begin{array}{l}\text { a. The pomegranate extract and its phenolics } \\
\text { may ameliorate the adverse effects against } \\
\mathrm{H}_{2} \mathrm{O}_{2} \text {-induced oxidative stress and cytotoxicity } \\
\text { in keratinocytes supports their utilization as } \\
\text { natural cosmeceuticals for skin health. }\end{array}$ & Liu et al. (2019) \\
\hline & $\begin{array}{l}\text { b. Pomegranate peel extract can prolong the } \\
\text { shelf-life of bighead carp fillets for about } 2 \\
\text { days, and it can be considered as a promising } \\
\text { preservative in aquatic products. }\end{array}$ & Zhuang et al. (2019) \\
\hline & $\begin{array}{l}\text { c. Pomegranate extract showed effectual at } \\
\text { protecting human skin fibroblasts from cell } \\
\text { death following UV exposure. }\end{array}$ & Pacheco-Palencia et al. (2008) \\
\hline & $\begin{array}{l}\text { d. Pretreatment of epiderm with pomegranate- } \\
\text { derived products resulted in inhibiting of } \\
\text { UVB-induced; collagenase gelatinase, } \\
\text { stromelysin, marilysin, elastase and } \\
\text { tropoelastin. }\end{array}$ & Afaq et al. (2009) \\
\hline Anti-liperoxidant activity & $\begin{array}{l}\text { Owing to the high anti-liperoxidant property } \\
\text { of pomegranate, acetone extract may have } \\
\text { possible application in the food industry. }\end{array}$ & Zhang et al. (2007) \\
\hline \multirow[b]{2}{*}{ Anti-obesity effects } & $\begin{array}{l}\text { a. A significant decrease in feed consumption } \\
\text { and body weight of female rats after exposure } \\
\text { them to a diet containing } 20 \% \text { of pomegranate } \\
\text { extract }(6 \%) \text { for } 37 \text { days. }\end{array}$ & Cerda et al. (2003) \\
\hline & $\begin{array}{l}\text { b. The pomegranate lead extract in a mouse } \\
\text { model of high-fat diet-induced obesity, and the } \\
\text { effects appear to be partly mediated by } \\
\text { inhibiting pancreatic lipase activity and } \\
\text { suppressing energy intake. }\end{array}$ & Lei et al. (2007) \\
\hline Anti-viral effects & $\begin{array}{l}\text { The crude pomegranate peel extract and its } \mathrm{n} \text { - } \\
\text { butanol and ethyl acetate fractions had the } \\
\text { highest inhibitory effect against influenza A } \\
\text { virus with IC50 value of } 6.45,6.07 \text { and } 5.6 \\
\mu \mathrm{g} / \mathrm{ml} \text { in Madin-Darby Canine Kidney } \\
\text { (MDCK) cells, respectively. }\end{array}$ & Moradi et al. (2019) \\
\hline Anti-ulcer effects & $\begin{array}{l}\text { The pomegranate peel extract, especially sour } \\
\text { summer has curative potential as an antiulcer, } \\
\text { possibly via its high antioxidant activity. }\end{array}$ & Moghaddam et al. (2013) \\
\hline \multirow{2}{*}{ Oral health management } & $\begin{array}{l}\text { a. Pomegranate juice is efficacious against } \\
\text { dental plaque microorganisms. }\end{array}$ & Kote et al. (2011) \\
\hline & $\begin{array}{l}\text { b. Hydroalcoholic extract was effectual against } \\
\text { dental plaque microorganisms. }\end{array}$ & Menezes et al. (2006) \\
\hline \multirow[t]{2}{*}{ Sexual behavior } & $\begin{array}{l}\text { a. Administration of the pomegranate extract } \\
\text { orally at the dose of } 1500 \mathrm{mg} / \mathrm{kg} \text { produced } \\
\text { significant augment of sexual activity in male } \\
\text { rats. }\end{array}$ & Lydia et al. (2019) \\
\hline & $\begin{array}{l}\text { b. Pomegranate juice consumption led to an } \\
\text { increase in epididymal sperm concentration, }\end{array}$ & Turk et al. (2008) \\
\hline
\end{tabular}




\begin{tabular}{|c|c|c|}
\hline & $\begin{array}{l}\text { sperm motility, spermatogenic cell density, and } \\
\text { the diameter of seminiferous tubules and } \\
\text { germinal cell layer thickness; it also decreased } \\
\text { the abnormal sperm rate when compared to } \\
\text { the control group. }\end{array}$ & \\
\hline & $\begin{array}{l}\text { c. Ellagic acid has a protective effect against } \\
\text { testicular and spermatozoa toxicity induced by } \\
\text { cyclosporine A. }\end{array}$ & Turk et al. (2010) \\
\hline Vertigo & $\begin{array}{l}\text { Pomegranate concentrated juice as a stomach } \\
\text { tonic led to the improvement of the digestive } \\
\text { symptoms and vertigo. }\end{array}$ & Monfared et al. (2019) \\
\hline \multirow{3}{*}{ Wound healing } & $\begin{array}{l}\text { a. The extract of the top layer of the peel } \\
\text { significantly improved the wound healing } \\
\text { process, but the pulp showed no promising } \\
\text { impacts. }\end{array}$ & $\begin{array}{l}\text { GhasemiPirbalouti et al. (2010) } \\
\text { Elzayat et al. (2018) } \\
\text { Sheikh Asadi et al. (2018) }\end{array}$ \\
\hline & $\begin{array}{l}\text { b. The ethanol extract of pomegranate exocarp } \\
\text { has the higher amounts of tannins and } \\
\text { flavonoids, compounds that are known to be } \\
\text { beneficial for wound healing. }\end{array}$ & $\begin{array}{l}\text { Ghaleh Mohammadi and Mirghazanfari } \\
\qquad(2019)\end{array}$ \\
\hline & $\begin{array}{l}\text { c. } 10 \% \text { standardized pomegranate extract } \\
\text { accelerates the healing of deep second-degree } \\
\text { burn wound, and pomegranate standardized } \\
\text { with } 40 \% \text { ellagic acid is a promising for the } \\
\text { healing of burn wound skin. }\end{array}$ & Lukiswanto et al. (2019) \\
\hline
\end{tabular}

The most important biological effects of methanol extract of pomegranate fruits are antiestrogenic in breast, no induction of proliferation in endometrial, ovarian, and cervical cancer cells, suppressed TNF $\alpha$ mediated endothelial cell apoptosis, estrogen inducible gene expression was not altered, reduced LDL cholesterol levels cardioprotective effect, no DNA adduct formation or oxidative DNA damage and has osteoprotective effects (Sreekumar et al., 2014). Fruit peel administration showed a noteworthy amelioration of abnormalities related Cd-nephrotoxicity (El-Habibi, 2013), and flower extract has protective role and ameliorate nephrotoxicity induced by gentamicin (El-Daly, 2016). The methanolic extract of peels was a potent inhibitor for Listeria monocytogenes, S. aureus, Escherichia coli, and Yersinia enterocolitica (Al-Zoreky, 2009; Devatkal et al., 2013). Extracts from fruit skin showed good antibacterial activity against $S$. aureus and $P$. aeruginosa (Sadeghian et al., 2011); and tannin from the pericarp is a very effective constituent against genital herpes virus (HSV-2) (Zhang et al., 1995). Acidity of pomegranate juice and concentrated liquid extract (POMxl) solutions contributed to rapid anti-influenza activity (Sundararajan et al., 2010), and treated mice with pomegranate peel significantly showed reduction in parasitemia as compared to untreated control (Mubaraki et al., 2016). Water extracts from arils has shown antibacterial effects against Bacillus megaterium, P. aeruginosa, S. aureus, Corynebacterium xerosis, E. coli, Enterococcus faecalis and Micrococcusluteus (Duman et al., 2009), and the aqueous and methanol extracts from whole fruit showed antibacterial effects on S. typh, Salmonella typhimurium, and Salmonella paratyphi (Pasha et al., 2009). Nascimento et al. (2000) showed antibacterial effects of ethanol extracts of the whole fruit on P. aeruginosa, and B. subtilis, and Salgado et al. (2009) indicated the antibacterial effects of raw extract of pomegranate whole fruit on $P$. aeruginosa, $E$. coli, Enteroccoccus faecalis, Enterobacter aerogenes, $S$. aureus and Microccocus luteus. The most important health benefits of pomegranate are shown in Figure 1. 


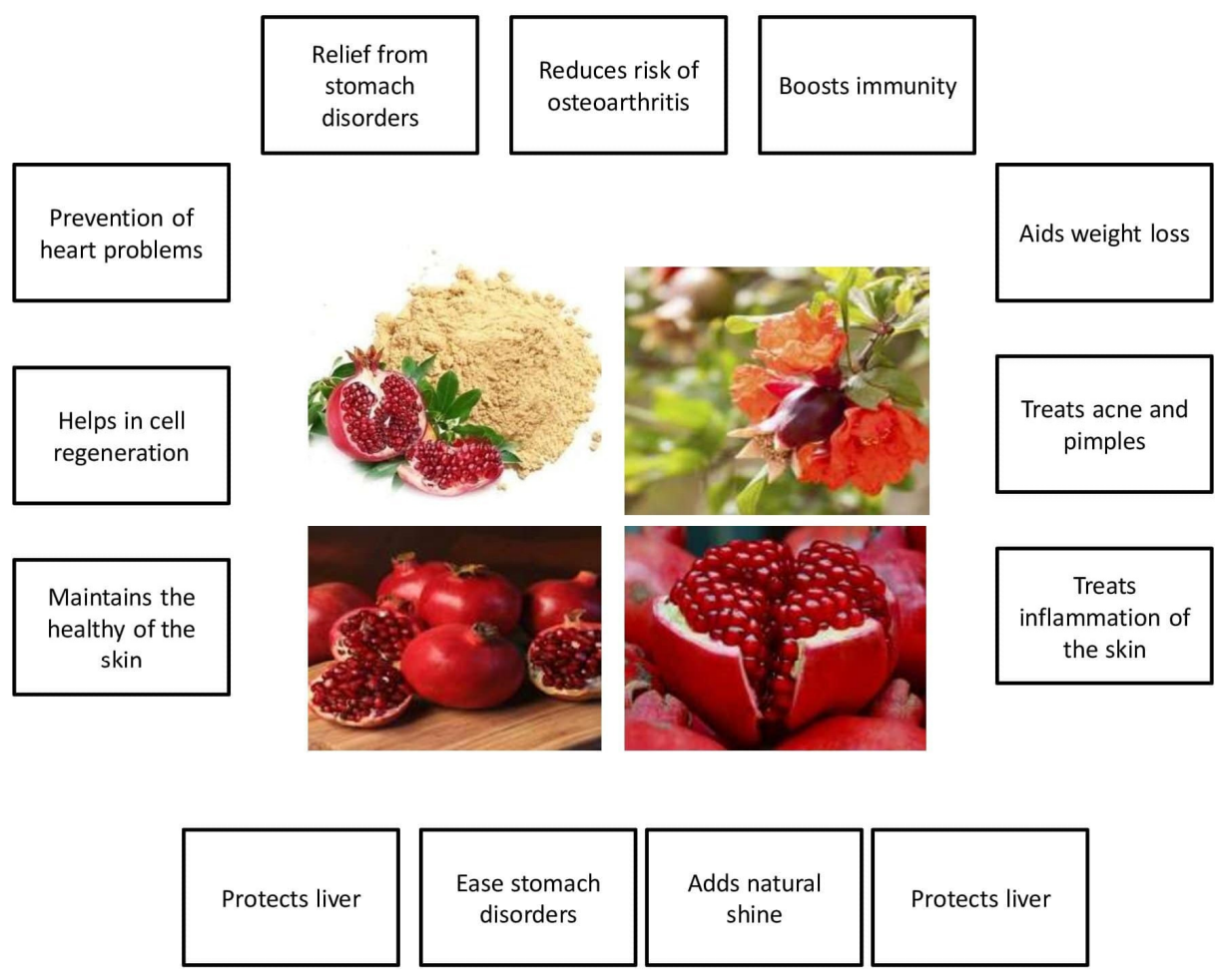

Figure 1. The most important health benefits of pomegranate

\section{Conclusions}

Pomegranate is native to Persia and Mediterranean zone which has been widely used in many countries and cultures, especially in west and center of Asia. Nutrient content of pomegranate peel is total solid, moisture, total sugars, reducing sugars, protein, crude fiber, fat content and ash. Fatty acids found in pomegranate seeds are caproic acid, punicic acid, capric acid, lauric acid, myristic acid, myristoleic acid, palmitic acid, palmitoleic acid, stearic acid, linoleic acid and oleic acid. Chemical compounds in pomegranate peels are gallic acid, ellagic acid, punicalin, punicalagin, caffeic acid, ellagitannins, pelletierine, alkaloids, luteolin, kaempferol and quercetin. Chemical constituents in pomegranate seeds are 3,3-Di- $O$-methylellagic acid, 3,3,4-Tri- $O$ methylellagic acid, punicic acid, pleic acid, palmitic acid, stearic acid, linoleic acid, sterols, tocopherols and sex steroids. Chemical compounds in pomegranate juice are simple sugars, aliphatic organic acids, gallic acid, ellagic acid, quinic acid, flavonols, amino acids, minerals, EGCG, and ascorbic acid. Pomegranate leave contains carbohydrates, reducing sugars, sterols, saponins, flavanoids, tannins, piperidine alkaloids, flavone, glycoside, and ellagitannins. The main chemical compounds in root and bark are ellagitannins, piperidine alkaloids, pyrrolidine alkaloid, and pelletierine alkaloids. Flower chemical constituents are gallic acids, ursolic acid, triterpenoids, and fatty acids. The most important potential benefits of pomegranate are antioxidant, cancer prevention, Alzheimer's disease protection, reduce inflammation in the gut and improve digestion, a powerful anti-inflammatory fruit, positive contributes to osteoarthritis and cartilage damage, heart-healthy juice, may lower systolic blood pressure, antiviral effects, improve learning and memory, a good source for potential fertility aid, a traditional remedy for diabetes, rich in different vitamins such as vitamin C, E, K., and a good source of folate and potassium. 


\section{Authors' Contributions}

All authors contributed equally to literature research, writing manuscript, etc. All authors read and approved the final manuscript.

\section{Acknowledgements}

This work was supported by the National Key R\&D Program of China
(Research grant 2019YFA0904700). This research wa also funded by the
Natural Science Foundation of Beijing, China (Grant No. M21026).

\section{Conflict of Interests}

The authors declare that there are no conflicts of interest related to this article.

\section{References}

Abbasi H, Rezaei K, Emamdjomeh Z, Mousavi SME (2008). Effect of various extraction conditions on the phenolic contents of pomegranate seed oil. European Journal of Lipid Science and Technology 110:668. https://doi.org/10.1002/ejlt.200890027

Abdel-Hafeez EH, Ahmed AK, Abdellatif MZM, Kamal AM, Toni NDM (2016). The efficacy of pomegranate (Punica granatum) peel extract on experimentally infected rats with Blastocystis Spp. Journal of Infectious Diseases and Preventive Medicine 4(1):1-6. https://doi.org/10.4172/2329-8731.1000131

Abdellatif AAH, Alawadh SH, Bouazzaoui A, Alhowail AH, Mohammed HA (2020). Anthocyanins rich pomegranate cream as a topical formulation with anti-aging activity. Journal of Dermatological Treatment. https://doi.org/10.1080/09546634.2020.1721418

Abdel Moneim AE, Othman MS, Mohmoud SM, El-Deib KM (2013). Pomegranate peel attenuates aluminum-induced hepatorenal toxicity. Toxicology Mechanisms and Methods 23(8):624-633. https://doi.org/10.3109/15376516.2013.823634

Abdolhosseini S, Hashem-Dabaghian F, Mokaberinejad R, Sadeghpour O, Mehrabani M (2017). Effects of pomegranate and spearmint syrup on nausea and vomiting during pregnancy: A randomized controlled clinical trial. Iran Red Crescent Medical Journal 19(10):e13542. https://doi.org/10.5812/ircmj.13542

Abid M, Cheikhrouhou S, Renard CMGC, Bureau S, Cuvelier G, Attia H, Ayadi MA (2017). Characterization of pectins extracted from pomegranate peel and their gelling properties. Food Chemistry 215:318-325. https://doi.org/10.1016/j.foodchem.2016.07.181

Achraf A, Hamdi C, Turki M, Abdelkarim O, Ayadi F, Hoekelmann A, Yaich S, Souissi N (2018). Natural pomegranate juice reduces inflammation, muscle damage and increase platelets blood levels in active healthy Tunisian aged med. Alexandria Journal of Medicine 54(1):45-48. https://doi.org/10.1016/j.ajme.2017.03.005

Adams LS, Zhang Y, Seeram NP, Heber D, Chen S (2010). Pomegranate ellagitannin-derived compounds exhibit antiproliferative and antiaromatase activity in breast cancer cells in vitro. Cancer Prevention Research (Phila.) 3(1):108-113. https://doi.org/10.1158/1940-6207.capr-08-0225

Adhami VM, Mukhtar H (2006). Polyphenols from green tea ad pomegranate for prevention of prostate cancer. Free Radical Research 40(10):1095-1104. https://doi.org/10.1080/10715760600796498

AdhamiVM, Khan N, Mukhtar H (2009). Cancer chemopreventive by pomegranate: Laboratory and clinical evidence. Nutrition and Cancer 61(6):811-815. https://doi.org/10.1080/01635580903285064

Afaq F, Zaid MA, Khan N, Dreher M, Mukhtar H (2009). Protective effect of pomegranate derived products on UVBmediated damage in human reconstituted skin. Experimental Dermatology 18(6):553-561. https://doi.org/10.1111/j.1600-0625.2008.00829.x 
Afaq F, Khan N, Syed DN, Mukhtar H (2010). Oral feeding of pomegranate fruit extract inhibits early biomarkers of UVB radiation-induced carcinogenesis in SKH-1 hairless mouse epidermis. Photochemistry and Photobiology 86(6):1318-1326. https://doi.org/10.1111/j.1751-1097.2010.00815.x

Ahmad T, Maheshwari SK, Siddiqui S, Latfar (2018). Nutritional and medicinal evaluation of pomegranate. Journal of Chemical and Pharmaceutical Research 10(10):84-104.

Ahmadiankia N (2019). Molecular targets of pomegranate (Punica granatum) in preventing cancer metastasis. Iranian Journal of Basic Medical Sciences 22:977-988.

Akuru EA, Oyeagu CE, Mpendulo TC, Rautenbach F, Oguntibeju OO (2020). Effect of pomegranate (Punica granatum L.) peel powder meal dietary supplementation on antioxidant status and quality of breast meat in broilers. Heliyon 6:e05709. https://doi.org/10.1016/j.heliyon.2020.e05709

Ali A, Chen Y, Liu H, Yu L, Baloch Z, Khalid S, Zhu J, Chen L (2019). Starch-based antimicrobial films functionalized by pomegranate peel. International Journal of Biological Macromolecules 129:1120-1126. https://doi.org/10.1016/j.ijbiomac.2018.09.068

Alimoradian A, Changizi-Ashtiyani S, Ghiasabadi Farahani A, KhederL, Rajabi R, Sharifi A (2017). Protective effects of pomegranate juice on nephrotoxicity induced by captopril and gentamicin in rats. Iranian Journal of Kidney Diseases 11(6):422-429.

Almuhayawi MS, Ramadan WS, HarakehS, Al Jaouni SK, Bharali DJ, Mousa SA, and Almuhayawi SM (2020). The potential role of pomegranate and its nano-formulations on cerebral neurons in aluminum chloride induced Alzheimer rat model. Saudi Journal of Biological Sciences 27:1710-1716. https://doi.org/10.1016/j.sjbs.2020.04.045

Al-Zoreky NS (2009). Antimicrobial activity of pomegranate (Punica granatum L.) fruit peels. International Journal of Food Microbiology 134(3):244-248. https://doi.org/10.1016/j.ijfoodmicro.2009.07.002

Amakura Y, Okada M, Tsuji S, Tonogai Y (2000). Determination of phenolic acids in fruit juices by isocratic column liquid chromatography. Journal of Chromatography A 891(1):183-188. https://doi.org/10.1016/s00219673(00)00625-7

Amin GR (1991). Iranian Traditional Medicinal Plants. Tehran, Iran: Farhang Publications.

Amri Z, Kharroubi W, Fidanzi-Dugas C, Leger DY, Hammami M, Liagre B (2020). Growth inhibitory and pro-apoptotic effects of ornamental pomegranate extracts in Du145 human prostate cancer cells. Nutrition and Cancer 72(6):932-938. https://doi.org/10.1080/01635581.2019.1660385

Andrade MA, Lima V, Silva AS, Vilarinho F, Catilho MC, Khwaldia K, Ramos F (2019). Pomegranate and grape byproducts and their active compounds: Are they a valuable source for food applications? Trends in Food Science and Technology 86:68-84. https://doi.org/10.1016/j.tifs.2019.02.010

Argov-Argaman N, Cohen-Zinder M, Leibovich H, Yishay M, Eitam H, Agmon R, ... Shabtay A (2020). Dietary pomegranate peel improves milk quality of lactating ewes: Emphasis on milk fat globule membrane properties and antioxidative traits. Food Chemistry 313:125822. https://doi.org/10.1016/j.foodchem.2019.125822

Asadi-Gharneh HA, Mohammadzamani M, Karimi S (2017). Evaluation of physic-chemical properties and bioactive compounds of some Iranian pomegranate cultivars. International Journal of Fruit Science 17(2):175-187. https://doi.org/10.1080/15538362.2016.1275923

Bakir S, Yazgan UC, Ibiloglu I, Elbey B, Kizil M, Kelle M (2015). The protective effect of pomegranate extract against cisplatin toxicity in rat liver and kidney tissue. Archives of Physiology and Biochemistry 121(4):152-156. https://doi.org/10.3109/13813455.2015.1068336

Balasubramani SP, Mohan J, Chatterjee A, Patnaik E, Kukkupuni SK, Nongthomba U, Venkatasubramanian P (2014). Pomegranate juice enhances healthy lifespan in Drosophila melanogaster: an exploratory study. Frontiers in Public Health 2(245):1-9. https://doi.org/10.3389/fpubh.2014.00245

Bassiri-Jshromi S, Pourshafie MR, MirabzadeArdakani E, Ehsani AH, Doostkam A, Katirae F, Mostafavi E (2018). In vivo comparative evaluation of the pomegranate (Punica granatum) peel extract as an alternative agent to nystatin against oral candidiasis. Iran Journal of Medical Science 43(3):296-304.

Bellesia A, Verzelloni E, Tagliazucchi D (2015). Pomegranate ellagitannins inhibit $\alpha$-glucosidase activity in vitro and reduce starch digestibility under simulated gastro-intestinal conditions. International Journal of Food Sciences and Nutrition 66(1):85-92. https://doi.org/10.3109/09637486.2014.953455

Ben-Simhon Z, Judeinstein S, Trainin T, Harel-Beja R, Bar-Ya'akov I, Borochov-Neori H, Holland D(2015). A "White" anthocyanin-less pomegranate (Punica granatum L.) caused by an insertion in the coding region of the 
leucoanthocyanidin dioxygenase (LDOX: ANS) gene. PloS One 10:21. https://doi.org/10.1371/journal.pone.0142777

Bertolo MRV, Martins VCA, Horn MM, Brenelli LB, Plepis AMG (2020). Rheological and antioxidant properties of chitosan/gelatin-based materials functionalized by pomegranate peel extract. Carbohydrate Polymers 228:115386. https://doi.org/10.1016/j.carbpol.2019.115386

Betanzos-Cabrera G, Montes-Rubio PY, Fabela-Illescas HE, Belefant-Miller H, Cancino-Diaz JC (2015). Antibacterial activity of fresh pomegranate juice against clinical strains of Staphylococcus epidermidis. Food and Nutrition Research 59(1):27620. https://doi.org/10.3402/fnr.v59.27620

Boggula N, Peddapalli H (2017). Phytochemical analysis and evaluation of in vitro antioxidant activity of Punica granatum leaves. International Journal of Pharmacognosy and Phytochemical Research 9(8):1110-1118. https://doi.org/10.25258/phyto.v9i08.9618

Bounihi A, Bitam A, Bouazza A, Yargui L, Ahmed Koceir E (2017). Fruit vinegars attenuate cardiac injury via antiinflammatory and anti-adiposity actions in high-fat diet-induced obese rats. Pharmaceutical Biology 55(1):43-52. https://doi.org/10.1080/13880209.2016.1226369

Bouroshaki MT, Sadeghnia HR, Banihasan M, Yavari S (2010). Protective effect of pomegranate seed oil on hexachlorobutadiene-induced nephrotoxicity in rat kidneys. Renal Failure 32(5):612-617. https://doi.org/10.3109/08860221003778056

Cerda B, Ceron JJ, Tomas-Barberan FA, Espin JC (2003). Repeated oral administration of high doses of pomegranate ellagitannin punicalagin to rats for 37 days in not toxic. Journal of Agricultural and Food Chemistry 51:34933501. https://doi.org/10.1021/jf020842c

Chaitra RH, Madhuri M, Swaroop T, Arijit D, Sourav B, Rohit KC (2012). Evaluation of antimicrobial properties, phytochemical contents and antioxidant capacity of leaf extracts of Punica granatum L. Journal of Biological Sciences 1:32-37.

Dadashi S, Mousazadeh M, Emam-Djomeh Z, Mousavi SM (2013). Pomegranate (Punica granatum L.) seed: A comparative study on biochemical composition and oil physicochemical characteristics. International Journal of Advanced Biological and Biomedical Research 1(4):351-363.

Dana N, Javanmard SH, Rafiee L (2015). Antiangiogenic and antiproliferative effects of black pomegranate peel extract on melanoma cell line. Research in Pharmaceutical Sciences 10(2):117-124. https://doi.org/10.7324/japs.2015.50109

Dana N, Haghjooy J, Rafiee L (2016). Role of peroxisome proliferator-activated receptor alpha and gamma in antiangiogenic effect of pomegranate peel extract. Iranian Journal of Basic Medical Sciences 19:106-110. https://doi.org/10.32388/schnwf

Demiray E, Karatay SE, Donmez G (2018). Evaluation of pomegranate peel in ethanol production by Saccharomyces cerevisiae and Pichia stipitis. Energy 159:988-994. https://doi.org/10.1016/j.energy.2018.06.200

Deng Y, Li Y, Yang F, Zing A, Yang S, Luo Y, ... Yin W (2017). The extract from Punica granatum (pomegranate) peel induces apoptosis and impairs metastasis in prostate cancer cells. Biomedicine and Pharmacotherapy 93:976-984. https://doi.org/10.1016/j.biopha.2017.07.008

Derakhshan Z, Ferrante M, Tadi M, Ansari F, Heydari A, Hosseini MS, Conti GO, Sadrabad EK (2018). Antioxidant activity and total phenolic content of ethanolic extract of pomegranate peels, juice and seeds. Food and Chemical Toxicology 114:108-111. https://doi.org/10.1016/j.fct.2018.02.023

Devatkal SK, Jaiswal P, Jha SN, Bharadwaj R, Viswas KN (2013). Antibacterial activity of aqueous extract of pomegranate peel against Pseudomonas stutzeri isolated from poultry meat. Journal of Food Science and Technology 50(3):555560. https://doi.org/10.1007/s13197-011-0351-y

Doostan F, Mesgari Abbasi M, KhordadmehrM, Fallah F, Behrouzy A (2019). Effects of pomegranate seed and peel methanolic extracts on methotrexate-induced hepatotoxicity in rats. Pharmaceutical Sciences 25(2):111-117. https://doi.org/10.15171/ps.2019.17

Drinic Z, Mudric J, Zdunic G, Bigovic D, Menkovic N, Savikin K (2020). Effect of pomegranate peel extract on the oxidative stability of pomegranate seed oil. Food Chemistry 333:127501. https://doi.org/10.1016/j.foodchem.2020.127501

Duman AD, Ozgen M, DayisoyluKS, Erbil N, Durgac C (2009). Antimicrobial activity of six pomegranate (Punica granatum L.) varieties and their relation to some of their pomological and phytonutrient characteristics. Molecules 14:1808-1817. https://doi.org/10.3390/molecules14051808 
El-Ashmawy NE, Khedr EG, El-Bahrawy HA, Abd El-Fattah EE (2016). Effect of pomegranate hull extract on liver neoplastic changes in rats: more than anti-oxidant. Nutrition and Cancer 68(6):1044-1051. https://doi.org/10.1080/01635581.2016.1192205

El-Barnossi A, Moussaid F, Housseini AI (2021). Tangerine, banana and pomegranate peels valorization for sustainable environment: A review. Biotechnology Reports 29:e00574. https://doi.org/10.1016/j.btre.2020.e00574

El Daly AA (2016). Pomegranate peels extract protects Cadmium-induced nephrotoxicity in albino mice. Journal of Bioscience and Applied Research 2:362-375. https://doi.org/10.21608/jbaar.2016.108529

El Darra N, Rajha HN, Saleh F, Al-Oweini R, Maroun RG, Louka N (2017). Food fraud detection in commercial pomegranate molasses syrups by UV-VIS spectroscopy, ATR-FTIR spectroscopy and HPLC methods. Food Control 78:132-137. https://doi.org/10.1016/j.foodcont.2017.02.043

El Habibi EM (2013). Renoprotective effects of Punica granatum (pomegranate) against adenine-induced chronic renal failure in male rats. Life Sciences Journal 10(4):2059-2069.

El-Hadary A, Taha M (2020). Pomegranate peel methanolic-extract improves the shelf-life of edible-oils under accelerated oxidation conditions. Food Science and Nutrition 8:1798-1811. https://doi.org/10.1002/fsn3.1391

El-Sayyad HIH, El-Gallil HA, El-Ghaweet HA (2020). Synergistic effects of pomegranate juice and atorvastatin for improving cerebellar structure and function of breast-feeding rats maternally fed on a high cholesterol diet. Journal of Chemical Neuroanatomy 107:101798. https://doi.org/10.1016/j.jchemneu.2020.101798

Elwej A, Ghorbel I, Marrekchi R, Boudawara O, Jamoussi K, Boudawara T, Zeghal N, Sefi M (2016). Improvement of kidney redox states contributes to the beneficial effects of dietary pomegranate peel against barium chlorideinduced nephrotoxicity in adult rats. Archives of Physiology and Biochemistry 122(3):130-140. https://doi.org/10.3109/13813455.2016.1150298

Elwej A, Salah GB, Kallel C, FakhfakhF, Zeghal N, Amara IB (2016). Protective effects of pomegranate peel against hematotoxicity, chromosomal aberrations, and genotoxicity induced by barium chloride in adult rats. Pharmaceutical Biology 54(6):964-974. https://doi.org/10.3109/13880209.2015.1087035

Elzayat EM, Auda SH, Alanazi FK, Al-Agamy MH (2018). Evaluation of wound healing activity of henna, pomegranate and myrrh herbal ointment blend. Saudi Pharmaceutical Journal 26:733738. https://doi.org/10.1016/j.jsps.2018.02.016

Ender P, Vural G, Nevzat A (2002). Organic acids and phenolic compounds in pomegranates (Punicagranatum L.) grown in Turkey. Journal of Food Composition and Analysis 15:567-575. https://doi.org/10.1006/jfca.2002.1071

Escarcega GH, Sanchez-Chavez E, Alvarez SP, Caballero MS, Parra JMS, Flores-Cordova MA, Salazar NAS, Barrios DLO (2020). Determination of antioxidant phenolic, nutritional quality and volatiles in pomegranates (Punica granatum L.) cultivated in Mexico. International Journal of Food Properties 23(1):979-991. https://doi.org/10.1080/10942912.2020.1760879

Faghihimani Z, Mirmiran P, Sohrab G, Iraj B, Faghihimani E (2016). Effects of pomegranate seed oil on metabolic state of patients with Type 2 diabetes mellitus. International Journal of Preventive Medicine 7:124. https://doi.org/10.4103/2008-7802.194883

Faisi J, Fattahi A, Raffel N, Hoffmann I, Beckmann MW, Schrauder M, Dittrich R, Lohberg C (2018). Effects of pomegranate seed oil and fermented juice polyphenols fractions in different solvents on copper-induced LDL oxidation. CyTA- Journal of Food 16(1):429-437. https://doi.org/10.1080/19476337.2017.1415375

Faria A, Calhau C (2011). The bioactivity of pomegranate: Impact on health and disease. Critical Reviews in Food Science and Nutrition 51(7):626-634. https://doi.org/10.1080/10408391003748100

Fazeli MR, Bahmani S, Jamalifar H, Samadi N (2011). Effect of probiotication on antioxidant and antibacterial activities of pomegranate juices from sour and sweet cultivars. Natural Product Research 25(3):288-297. https://doi.org/10.1080/14786419.2010.495068

Fischer UA, Carle R, Kammerer DR (2011). Identification and quantification of phenolic compounds from pomegranate (Punica granatum L.) peel, mesocarp, aril and differently produced juices by HPLC-DAD-ESI/MSn. Food Chemistry 127(2):807-821. https://doi.org/10.1016/j.foodchem.2010.12.156

George J, Singh M, Srivastava AK, Bhui K, Shukla Y (2011). Synergistic growth inhibition of mouse skin tumors by pomegranate fruit extract and diallyl sulfide evidence for inhibition of activated MAPKs/NF-happaB and reduced cell proliferation. Food Chemistry and Toxicology 49(7):1511-1520. https://doi.org/10.1016/j.fct.2019.110784

Ghaleh Mohammadi MO, Mirghazanfari SM (2019). Investigation of Iranian pomegranate cultivars for wound healing components. European Journal of Translational Myology 29(1):22-26. https://doi.org/10.4081/ejtm.2019.7995 
GhasemiPirbalouti A, Koohpayeh A, Karimi I (2010). The wound healing activity of flower extracts of Punica granatum and Achillea kellalensis in wistar rats. Acta Poloniae Pharmaceutica- Drug Research 67(1):107-110.

Gil MI, Tomas-Barberan FA, Hess-Pierce B, Holcroft DM, Kader AA (2000). Antioxidant activity of pomegranate juice and its relationship with phenolic composition and processing. Journal of Agricultural and Food Chemistry 48(10):4581-4589. https://doi.org/10.1021/jf000404a

Glazer I, Masaphy S, Marciano P, Bar-Ilan I, Holland D, Kerem Z, Amir R (2012). Partial identification of antifungal compounds from Punica granatum peel extracts. Journal of Agricultural and Food Chemistry 60(19):4841-4848. https://doi.org/10.1021/jf300330y

Gould SWJ, Fielder MD, Kelly AF, El Sankary W, Naughton DP (2009). Antimicrobial pomegranate rind extracts: enhancement by $\mathrm{Cu}$ (II) and vitamin $\mathrm{C}$ combinations against clinical isolates of Pseudomonas aeruginosa. British Journal of Biomedical Science 66(3):129-132. https://doi.org/10.1080/09674845.2009.11730258

Govindappa M, Tejashree S, Thanuja V, Hemashekhar B, Srinivas C, Nasif O, Pugazhendhi A, Raghavendra VB (2021). Pomegranate fruit fleshy pericarp mediated silver nanoparticles possessing antimicrobial, antibiofilm formation, antioxidant, biocompatibility and anticancer activity. Journal of Drug Delivery Science and Technology 61:102289. https://doi.org/10.1016/j.jddst.2020.102289

Grabez M, Skrbic R, Stojiljkovic MP, Rudic-Grujic V, Paunovic M, Arsic A, ... Vasiljevic N (2020). Beneficial effects of pomegranate peel extract on plasma lipid profile, fatty acids levels and blood pressure in patients with diabetes mellitus type-2: A randomized, double-blind, placebo-controlled study. Journal of Functional Foods 64:103692. https://doi.org/10.1016/j.jff.2019.103692

Gul HF, Ilhan N, Ilhan N, Ozercan IH, Kuloglu T (2021). The combined effect of pomegranate extract and tangeretin on the DMBA-induced breast cancer model. The Journal of Nutritional Biochemistry 89:108566. https://doi.org/10.1016/j.jnutbio.2020.108566

Guler Z, Gul E (2017). Volatile organic compounds in the aril juices and seeds from selected five pomegranate (Punica granatum L.) cultivars. International Journal of Food Properties 20(2):281-293. https://doi.org/10.1080/10942912.2016.1155057

Guo CJ, Wei Y, Yang JJ, Li YF, Xu J, Jiang YG (2003). The antioxidant capacity of 66 vegetables and fruits: a comparative study. Acta Nutrimenta Sinica 25:203-207.

Guo CJ, Yang JJ, Wei JY, Li YF, Xu J, Jiang YG (2003). Antioxidant activities of peel, pulp and seed fractions of common fruits, as determined by by FRAP assay. Nutrition Research 23:1719-1726. https://doi.org/10.1016/j.nutres.2003.08.005

Habibnia M, Ghavami M, Ansaripour M, Vosough S (2012). Chemical evaluation of oils extracted from five different varieties of Iranian pomegranate seeds. Journal of Food Biosciences and Technology 2:35-40.

Hasnaoui N, Jbir R, Mars M, Trifi M, Kamal-Eldin A, Melgarejo P, Hernandez F (2011). Organic acids, sugars, and anthocyanins contents in juices of Tunisian pomegranate fruits. International Journal of Food Properties 14(4):741-757. https://doi.org/10.1080/10942910903383438

Hasnaoui N, Wathelet B, Jimenez-Araujo A (2014). Valorization of pomegranate peel from 12 cultivars: dietary fibre composition, antioxidant capacity and functional properties. Food Chemistry 160:196-203. https://doi.org/10.1016/j.foodchem.2014.03.089

HassanpourFard M, Ghule AE, Bodhankar SL, Dikshit M (2011). Cardioprotective effect of whole fruit extract of pomegranate on doxorubicin-induced toxicity in rat. Pharmaceutical Biology 49(4):377382. https://doi.org/10.3109/13880209.2010.517758

He L, Lan W, Ahmed S, Qin W, Liu Y (2019). Electrospun polyvinyl alcohol film containing pomegranate peel extract and sodium dehydroacetate for use as food packaging. Food Packaging and Shelf Life 22:100390. https://doi.org/10.1016/j.fpsl.2019.100390

Hornung E, Pernstich C, Feussner I (2002). Formation of conjugated $\Delta 11 \Delta 13$-double bonds by $\Delta 12$-linoleic acid $(1,4)$ acyl-lipid-desaturase in pomegranate seeds. European Journal of Biochemistry 269(19):4852-4859. https://doi.org/10.1046/j.1432-1033.2002.03184.x

Huang THW, Peng G, Kota BP (2005). Anti-diabetic action of Punica granatum flower extract: activation of PPAR- $\gamma$ and identification of an active component. Toxicology and Applied Pharmacology 207(2):160-169. https://doi.org/10.1016/j.taap.2004.12.009

Houston DMJ, Bugert JJ, Denyer SP, Heard CM (2017). Potentiated virucidal activity of pomegranate rind extract (PRE) and punicalagin against Herpes simplex virus (HSV) when co-administered with zinc (II) ions, and antiviral 
activity of PRE against HSV and aciclovir-resistant HSV. PloS One 12(6):e0179291. https://doi.org/10.1371/journal.pone.0179291

Ismail OM, Younis RA, Ibrahim AM (2014). Morphological and molecular evaluation of some Egyptian pomegranate cultivars. African Journal of Biotechnology 13(2). https://doi.org/10.5897/ajb2013.13035

Jagdale S, Ahiwale S, Gajbhiye M, Kapadnis B (2019). Green approach to phytopathogen: Characterization of lytic bacteriophages of Pseudomonas sp., an etiology of the bacterial blight of pomegranate. Microbiological Research 228:126300. https://doi.org/10.1016/j.micres.2019.126300

Jaiswal V, DerMarderosian A, Porter JR (2010). Anthocyanins and polyphenol oxidase from dried arils of pomegranate (Punica granatum L.). Food Chemistry 118:11-16. https://doi.org/10.1016/j.foodchem.2009.01.095

Jandari S, Hatami E, Ziaei R, Ghavai A, Yamchi AM (2020). The effect of pomegranate (Punica granatum) supplementation on metabolic status in patients with type 2 diabetes: A systematic review and meta-analysis. Complementary Therapies in Medicine 52:102478. https://doi.org/10.1016/j.ctim.2020.102478

Jesse Joel T, Suluvoy JK, Varghese J (2019). Evaluation of the secondary metabolites of the waste pomegranate rind and its cytotoxicity against oral cancer (KB 3-1). Journal of Pure and Applied Microbiology 13(3):1667-1672. https://doi.org/10.22207/jpam.13.3.40

Joseph MM, Aravind SR, Varghese S, Mini S, Sreelekha TT (2012). Evaluation of antioxidant, antitumor and immunomodulatory properties of polysaccharide isolated from fruit of Punica granatum. Molecular Medicine Reports 5(2):489-496.

Kam A, Li KM, Razmovski-Naumovski V, Nammi S, Chan K, Li GQ (2013). Variability of the polyphenolic content and antioxidant capacity of methanolic extracts of pomegranate peel. Natural Product Communications 8(6):707710. https://doi.org/10.1177/1934578x1300800607

Karimi M, Sadeghi R, Kokini J (2017). Pomegranate as a promising opportunity in medicine and nanotechnology. Trends in Food Science and Technology 69(Part A):59-73. https://doi.org/10.1016/j.tifs.2017.08.019

Karwasra R, Singh S, Sharma D, Sharma S, Sharma N, Khanna K (2019). Pomegranate supplementation attenuates inflammation, joint dysfunction via inhibition of NF- $\kappa \mathrm{B}$ signaling pathway in experimental models of rheumatoid arthritis. Journal of Food Biochemistry E12959:1-12. https://doi.org/10.1111/jfbc.12959

Katana LK, Maina CI, Orenge CO, Kirui CK, Muriuki G, Waithaka PN (2019). Effectiveness of pomegranate (Punica granatum L.) fruit extract on the sexual functional in rats. Journal of Microbial and Biochemical Technology $11(4): 424$.

Kennas A, Amellal-Chibane H, Kessal F, Halladj F (2020). Effect of pomegranate peel and honey fortification on physicochemical, physical, microbiological and antioxidant properties of yoghurt powder. Journal of the Saudi Society of Agricultural Sciences 19:99-108. https://doi.org/10.1016/j.jssas.2018.07.001

Khalid S, Yu L, Feng M, Meng L, Bai Y, Ali A, Liu H, Chen L (2018). Development and characterization of biodegradable antimicrobial packaging films based on polycaprolactone, starch and pomegranate rind hybrids. Food Packaging and Shelf Life 18:71-79. https://doi.org/10.1016/j.fpsl.2018.08.008

Khan N, Hadi N, Afaq F, Syed DN, Kweon MH, Mukhtar H (2007). Pomegranate fruit extract inhibits prourvival pathways in human A549 lung carcinoma cells and tumor growth in athymic nude mice. Carcinogenesis 28(1):163-173. https://doi.org/10.1093/carcin/bg/145

Khan N, Afaq F, Mukhtar H (2008). Cancer chemoprevention through dietary antioxidants: progress and promise. Antioxidants Redox Signal 10:475-510. https://doi.org/10.1089/ars.2007.1740

Khan GN, Gorin MA, Rosenthal D, Pan Q, Bao LW, Wu ZF, ... Merajver SD (2009). Pomegranate fruit extract impairs invasion and motility in human breast cancer. Integrative Cancer Therapies 8(3):242253. https://doi.org/10.1177/1534735409341405

Khan NH, Ying ALT, Tian CGZ, Yi OW, Vijayabalan S (2017). Screening of Punica Granatum seeds for antibacterial and antioxidant activity with various extracts: A brief analytical study. Current Advances in Chemistry and Biochemistry 8:146-159. https://doi.org/10.35841/biotechnology-phytochemistry.1.1.1-7

Kho YL, Jung W, Kwon D, Kim JH (2010). Identification of estrone in pomegranate (Punica granatum) extracts by liquid chromatography-tandem mass spectrometry. Food Science and Biotechnology 19(3):809-813. https://doi.org/10.1007/s10068-010-0113-Z

Khorrami S, Zarepour A, Zarrabi A (2019). Green synthesis of silver nanoparticles at low temperature in a fast pace with unique DPPH radical scavenging and selective cytotoxicity against MCF-7 and BT-20 tumor cell lines. Biotechnology Reports 24:e00393. https://doi.org/10.1016/j.btre.2019.e00393 
Kohno H, Suzuki R, Yasui Y, Hosokawa M, Miyashita K, Tanaka T (2004). Pomegranate seed oil rich in conjugated linolenic acid suppresses chemically induced colon carcinogenesis in rats. Cancer Science 95(6):481-486. https://doi.org/10.1111/j.1349-7006.2004.tb03236.x

Kotamballi, Chidambara Murthy N, Guddadarangavvahally, Jayaprakasha K, Singh RP (2002). Studies on antioxidant activity of pomegranate (Punica granatum) peel extract using in vivo models. Journal of Agriculture and Food Chemistry 50(17):4791-4795. https://doi.org/10.1021/jf0255735

Kote S, Kote S, Nagesh L (2011). Effect of pomegranate juice on dental plaque micro-organisms (streptococci and lactobacilli). Ancient Science of Life 31(2):49-52. https://doi.org/10.4103/0257-7941.107364

Koyama S, Cobb LJ, Mehta HH, SeeramNP, Heber D, Pantuck AJ (2010). Pomegranate extract induces apoptosis in human prostate cancer cells by modulation of the IGF-IGFBP axis. Growth Hormone and IGF Research 20:5562. https://doi.org/10.1016/j.ghir.2009.09.003

Lan J, Lei F, Hua L, Wang Y, Xing D, Du L (2009). Transport behavior of ellagic acid of pomegranate leaf tannins and its correlation with total cholesterol alteration in HepG2 cells. Biomedical Chromatography 23(5):531-536. https://doi.org/10.1002/bmc.1150

Lansky E, Shubert S, Neeman I (2000). Pharmacological and therapeutic properties of pomegranate. Options Méditerranéennes. Série A, Séminaires Méditerranéens 42:231-235.

Lansky EP, Newman RA (2007). Punica granatum (pomegranate) and its potential for prevention and treatment of inflammation and cancer. Journal of Ethnopharmacology 109:177-206. https://doi.org/10.1016/j.jep.2006.09.006

Lantzouraki D, Sinanoglou VJ, Zoumpoulakis P, Proestos C (2016). Comparison of the antioxidant and antiradical activity of pomegranate (Punica granatum L.) by ultrasound-assisted and classical extraction. Analytical Letters 49(7):969-978. https://doi.org/10.1080/00032719.2015.1038550

Lee CJ, Chen LG, Liang WL, Wang CC (2010). Anti-inflammatory effects of Punica granatum in vitro and in vivo. Food Chemistry 118:315-322. https://doi.org/10.1016/j.foodchem.2009.04.123

Lee ST, Lu MH, Chien LH, Wu TF, Huang LC, Liao GI (2013). Suppression of urinary bladder urothelial carcinoma cell by the ethanol extract of pomegranate fruit through cell cycle arrest and apoptosis. BMC Complementary and Alternative Medicine 13:364. https://doi.org/10.1186/1472-6882-13-364

Lei F, Zhang XN, Wang W, Xing DM, Xie WD, Su H, Du LJ (2007). Evidence of anti-obesity effects of pomegranate leaf extract in high-fat-diet-induced obese mice. International Journal of Obesity 31(6):1023-1029. https://doi.org/10.1038/sj.ijo.0803502

Liu H, Zing Z, Wang S, Li T, Mastriani E, Li Q-H, ... Liu S-L (2017). Main components of pomegranate, ellagic acid and luteolin, inhibit metastasis of ovarian cancer by down-regulating MMP2 and MMP9. Cancer Biology and Therapy 18(12):990-999. https://doi.org/10.1080/15384047.2017.1394542

Liu C, Guo H, DaSilva NA, Li D, Zhang K, Wang Y, Gao X-H, Chen H-D, Seeram NP, Ma H (2019). Pomegranate (Punica granatum) phenolics ameliorate hydrogen peroxide-induced oxidative stress and cytotoxicity in human keratinocytes. Journal of Functional Foods 54:559-567. https://doi.org/10.1016/j.jff.2019.02.015

Lucci P, Pacetti D, Loizzo MR, Frega NG (2015). Punica granatum cv. Dente di Cavallo seed ethanolic extract: antioxidant and antiproliferative activities. Food Chemistry 167:475-483. https://doi.org/10.1016/j.foodchem.2014.06.123

Lukiswanto BS, Miranti A, Sudjarwo SA, Primarizky H, Yuniarti WM (2019). Evaluation of wound healing potential of pomegranate (Punica granatum) whole fruit extract on skin burn wound in rats (Rattus norvegicus). Journal of Advanced Veterinary and Animal Research 6(2):202-207. https://doi.org/10.5455/javar.2019.f333

Lydia KK, Charles IM, Caleb OO, Collins KK, Benson GM, Paul NW (2019). Effectiveness of pomegranate (Punica Granatum L.) fruit extract on the sexual function in rats. Journal of Microbial and Biochemical Technology 11(424):1-6.

Ma Y, Yin X, Bi X, Su F, Liang Z, Luo M, Fu D, Xing Y, Che Z (2019). Physicochemical properties and bioactive compounds of fermented pomegranate juice as affected by high-pressure processing and thermal treatment. International Journal of Food Properties 22(1):1250-1269. https://doi.org/10.1080/10942912.2019.1640737

Mahboubi A, Asgarpanah J, Sadaghiyani PN, Faizi M (2015). Total phenolic and flavonoid content and antibacterial activity of Punica granatum L. var. pleniflora flowers (Golnar) against bacterial strains causing foodborne diseases. Complementary and Alternative Medicine 15:366. https://doi.org/10.1186/s12906-015-0887-X

Mars M (2000). Pomegranate Plan material: genetic resources and breeding. A review. CIHEAM, Zaragoza, pp 55-62. 
Martinez L, Castillo J, Ros G, Nieto G (2019). Antioxidant and antimicrobial activity of rosemary, pomegranate and olive extracts in fish patties. Antioxidants 8(86):1-16. https://doi.org/10.3390/antiox8040086

Mastrogiovanni F, Bernini R, Basirico L, Bernabucci U, Campo M, Romani A, Santi L, Lacetera N (2020). Antioxidant and anti-inflammatory effects of pomegranate peel extracts on bovine mammary epithelial cells BME-UV1. Natural Product Research 34(10):1465-1469. https://doi.org/10.1080/14786419.2018.1508149

Mehta R, Lansky E P(2004). Breast cancer chemo-preventive properties of pomegranate (Punica granatum) fruit extracts in a mouse mammary organ culture. European Journal of Cancer Prevention 13:345-348. https://doi.org/10.1097/01.cej.0000136571.70998.5a

Melgarejo P, Nunez-Gomez D, Legua P, Martinez-Nicolas JJ, Almansa MS (2020). Pomegranate (Punica granatum L.) a dry pericarp fruit with fleshy seeds. Trends in Food Science and Technology 102:232-236. https://doi.org/10.1016/j.tifs.2020.02.014

Menezes SMS, Cordeiro LN, Viana GS (2006). Punica granatum (Pomegranate) extract is active against dental plaque. Journal of Herbal Pharmacotherapy 6(2):79-92. https://doi.org/10.1080/j157v06n02_07

Minaiyan M, Zolfaghari B, Taheri D, Gomarian M (2014). Preventive effect of three pomegranate (Punica granatum L.) seeds fractions on cerulean-induced acute pancreatitis in mice. International Journal of Preventive Medicine 5(4):394-404.

Mirdehghan SH, Rahemi M (2007). Seasonal changes of mineral nutrients and phenolics in pomegranate (Punica granatum L.). Scientia Horticulturae Fruit 111:120-127. https://doi.org/10.1016/j.scienta.2006.10.001

Mirzapour MH, Khoshgoftarmanesh AH (2013). Effect of soil and foliar application of iron and zinc on quantitative and qualitative yield of pomegranate. Journal of Plant Nutrition 36(1):55-66. https://doi.org/10.1080/01904167.2012.733049

Mo J, Panichayupakaranant P, Kaewnopparat N, Nitiruangjaras A, Reanmongkol W (2013). Topical anti-inflammatory and analgesic activities of standardized pomegranate rind extract in comparison with its marker compound ellagic acid in vivo. Journal of Ethno-Pharmacology 148(3):901-908. https://doi.org/10.1016/j.jep.2013.05.040

Moghaddam G, Sharifzadeh M, Hassanzadeh G, Khanavi M, Hajimahmoodi M (2013). Anti-ulcerogenic activity of the pomegranate peel (Punica granatum) methanol extract. Food and Nutrition Sciences 4:43-48. https://doi.org/10.4236/fns.2013.410a008

Moghadam M, Salami M, Mohammadian M, Khodadadi M, Emam-Djomeh Z (2020). Development of antioxidant edible films based on mung bean protein enriched with pomegranate peel. Food Hydrocolloids 104:105735. https://doi.org/10.1016/j.foodhyd.2020.105735

Mohapatra S(2014). Residue dynamics of chlorpyrifios and cypermethrin in/on pomegranate (Pubica granatum L.) fruits and soil. International Journal of Environmental Analytical Chemistry 94(14-15):1394-1406. https://doi.org/10.1080/03067319.2014.954564

Mollazadeh H, Sadeghnia HR, Hoseini A, Farzadnia M, Boroushaki MT (2016). Effects of pomegranate seed oil on oxidative stress markers, serum biochemical parameters and pathological findings in kidney and heart of $\begin{array}{llll}\text { streptozotocin-induced diabetic } & \text { rats. } & \text { Renal } & \text { Failure }\end{array}$ https://doi.org/10.1080/0886022x.2016.1207053

Monfared M, Karimi-Yazdi A, Dabaghian F, Amini BF (2019). Successful treatment of chronic vertigo with pomegranate concentrated juice: A report two cases. Iranian Red Crescent Medical Journal 21(2):e83103. https://doi.org/10.5812/ircmj.83103

Monir W, Abdel-Rahman MA, Hassan SE-D, Mansour ES, Awad SMM (2020). Pomegranate peel and moringa-based diets enhanced biochemical and immune parameters of Nile tilapia against bacterial infection by Aeromonas hydrophila. Microbial Pathogenesis 145:104202. https://doi.org/10.1016/j.micpath.2020.104202

Moradi M-T, Karimi A, Alidadi S, Gholami-Arjenaki M (2015). In vitro anti-herpes simplex type-1 activity, antioxidant potential and total phenolic compounds of pomegranate (Punica granatum L.) peel extract. Journal of Chemical and Pharmaceutical Research 7(8):82-88. https://doi.org/10.1177/2040206620916571

Moradi M-T, Karimi A, Shahrani M, Hashemi L, Ghaffari-Goosheh M-S (2019). Anti-influenza virus activity and phenolic content of pomegranate (Punica granatum L.) peel extract and fractions. Avicenna Journal of Medical Biotechnology 11(4):285-291.

Mortada WI, Awadalla A, Khater SM, Barakat NM, Husseiny SM, Shokeir AA (2020). Preventive effect of pomegranate juice against chemically induced bladder cancer: An experimental study. Heliyon 6:e05192. https://doi.org/10.1016/j.heliyon.2020.e05192 
Morvaridzadeh M, Sepidarkish M, Daneshzad E, Akbari A, Mobini GR, Heshmati J (2020). The effect of pomegranate on oxidative stress parameters: A systematic review and meta-analysis. Complementary Therapies in Medicine 48:102252. https://doi.org/10.1016/j.ctim.2019.102252

Mphahlele RR, Pathare PB, Opara UL (2019). Drying kinetics of pomegranate fruit peel (cv. Wonderful). Scientific African 5:e00145. https://doi.org/10.1016/j.sciaf.2019.e00145

Mubaraki MA, Hafiz TA, Dkhil MA, Al-Quraishy S (2016). Beneficial effect of Punica granatum peel extract on murine malaria-induced spleen injury. BMC Complementary and Alternative Medicine 16(1):221. https://doi.org/10.1186/s12906-016-1207-9

Nallanthighal S, Shirode AB, Judd JA, Reliene R (2016). Pomegranate intake protects against genomic instability induced by medical X-rays in vivo in mice. Nutrition and Cancer 68(8):1349-1356. https://doi.org/10.1080/01635581.2016.1225104

Nallanthighal S, Elmaliki KM, Relience R (2017). Pomegranate extract alters breast cancer stem cell properties in association with inhibition of epithelial-to-mesenchymal transition. Nutrition and Cancer 69(7):1088-1098. https://doi.org/10.1080/01635581.2017.1359318

Nascimento GGF, Locatelli J, Freitas PC, Silva GL (2000). Antibacterial activity of plant extracts and phytochemicals on antibiotic-resistant bacteria. Brazilian Journal of Microbiology 31:247-256. https://doi.org/10.1590/s151783822000000400003

Nawwar MAM, Hussein SAM, Merfort I (1994). Leaf phenolics of Punica granatum. Phytochemistry 37(4):1175-1177. https://doi.org/10.1016/s0031-9422(00)89552-7

Nazeam JA, Al-Shareef WA, Helmy MW, El-Haddad A (2020). Bioassay-guided isolation of potential bioactive constituents from pomegranate agrifood by-product. Food Chemistry 326:126993. https://doi.org/10.1016/j.foodchem.2020.126993

Nemati Z, Tehranifar A, Farsi M, Mirshamsi KA, Nemati H, Khayat M (2012). Evaluation of genetic diversity of Iranian pomegranate cultivars using fruit morphological characteristics and AFLP markers. Notulae Botanicae Horti Agrobotanici Cluj-Napoca 40(1):261-268. https://doi.org/10.15835/nbha4017369

Neuhofer H, Witte L, Gorunovic M, Czygan F-C (1993). Alkaloids in the bark of Punica granatum L. (Pomegranate) from Yugoslavia. Die Pharmazie 48(5):389-391.

Nozohour Y, Golmohammadi R, Mirnejad R, Fartashvand M (2018). Antibacterial activity of pomegranate (Punica granatum L.) seed and peel alcoholic extracts on Staphylococcus aureus and Pseudomonas aeruginosa isolated from health centers. Journal of Applied Biotechnology Reports 5(1):32-36. https://doi.org/10.29252/jabr.01.01.06

Nuamsetti T, Dechayuenyong P, Tantipaibulvut S (2012). Antibacterial activity of pomegranate fruit peels and arils. ScienceAsia 38:319-322. https://doi.org/10.2306/scienceasia1513-1874.2012.38.319

Orhan E, Ercisli S, Esitken A, Sengul M (2014). Molecular and morphological characterization of pomegranate (Punica granatum L.) genotypes sampled from Coruh valley in Turkey. Genetic and Molecular Research 13(3):6375-6382. https://doi.org/10.4238/2014.january.14.4

Ouachrif A, Khalki H, Chaib S, Mountassir M, Aboufatima R, Farouk L, Benharraf A, Chait A (2012). Comparative study of the anti-inflammatory and antinociceptive effects of two varieties of Punica granatum. Pharmaceutical Biology 50(4):429-438. https://doi.org/10.3109/13880209.2011.611142

Ozkan Y (2005). Investigations on physical and chemical characteristics of some pomegranate genotypes (Punica granatum L.) of Tokat province in Turkey. Asian Journal of Chemistry 17:939-942.

Pacheco-Palencia LA, Noratto G, Hingorani L, Talcott ST, Mertens-Talcott SU (2008). Protective effects of standardized pomegranate (Punica granatum L.) polyphenolic extract in ultraviolet-irradiated human skin fibroblasts. Journal of Agricultural and Food Chemistry 56(18):8434-8441. https://doi.org/10.1021/jf8005307

Pan L-H, Liu F, Luo S-Z, Luo J-P (2019). Pomegranate juice powder as sugar replacer enhanced quality and function of set yogurts: Structure, rheological property, antioxidant activity and in vitro bioaccessibility. LWT 115:108479. https://doi.org/10.1016/j.lwt.2019.108479

Parsaeyan N, Mozaffari-Khosravi H, Mozayan MR (2012). Effect of pomegranate juice on paraoxonase enzyme activity in patients with type 2 diabetes. Iranian Journal of Diabetes and Obesity 4(1):26-31. https://doi.org/10.1186/2251-6581-11-11

Pasha C, Sayeed S, Ali S, Khan Z (2009). Anti-salmonella activity of selected medicinal plants. Turkish Journal of Biology 33:59-64.

Paul A, Radhakrishnan M (2020). Pomegranate seed oil in food industry: Extraction, characterization, and applications. Trends in Food Science and Technology 105:273-283. https://doi.org/10.1016/j.tifs.2020.09.014 
Pirzadeh M, Caporaso N, Rauf A, Shariati MA, Yessimbekov Z, Khan MU (2020). Pomegranate as a source of bioactive constituents: a review on their characterization, properties and applications. Critical Reviews in Food Science and Nutrition. https://doi.org/10.1080/10408398.2020.1749825

Pontonio E, Montemurro M, Pinto D, Marzani B, Trani A, Ferrara G, ... Rizzello CG (2019). Lactic acid fermentation of pomegranate juice as a tool to improve antioxidant activity. Frontiers in Microbiology 10:1550. https://doi.org/10.3389/fmicb.2019.01550

Qabaha K, Al-Rimawi F, Nusseibeh S, Abbadi J, Abu-Lafi S (2019). Phenolic and flavonoids analysis of pomegranate peel extracts and their anti-inflammatory and antioxidant activities. International Journal of Pharmaceutical Quality Assurance 10(1):60-65. https://doi.org/10.25258/ijpqa.10.1.9

Qnais EY, Elokda AS, Abu Ghalyun YY, Abdulla FA (2007). Antidiarrheal activity of the aqueous extract of Punica granatum (Pomegranate) peels. Pharmaceutical Biology 45(9):715-720. https://doi.org/10.1080/13880200701575304

Rahimi AM, Jafarpour M, Pessarakli M (2017). Morpho-pomological and chemical properties of pomegranate (Punica granatum L.) cultivars in Iran. Journal of Plant Nutrition 40(10):1437-1442. https://doi.org/10.1080/01904167.2016.1269181

Rashidi A, Jafari-Menshadi F, Zinsaz A, Sadafi Z (2013). Effect of concentrated pomegranate juice consumption on glucose and lipid profile concentrations in type 2 diabetic patients. Zahedan Journal of Research in Medical Sciences 15(6):40-42.

Read E, Deseo MA, Hawes M, Rochfort S (2019). Identification of potentially cytotoxic phenolics present in pomegranates (Punica granatum L.). Animal Feed Science and Technology 251:187-197. https://doi.org/10.1016/j.anifeedsci.2019.03.012

Ridzwan N, Jumli MN, Baig AA, Rohin MAK (2020). Pomegranate-derived anthocyanin regulates MORscAMP/CREB-BDNF pathways in opioid-dependent models and improves cognitive impairments. Journal of Ayurveda and Integrative Medicine 11:478-488. https://doi.org/10.1016/j.jaim.2019.12.001

Rongai D, Pulcini P, Di Lernia G, Nota P, Preka P, Milano F (2019). Punicalagin content and antifungal activity of different pomegranate (Punica ganatum L.) genotypes. Horticulture 5(52):1-9. https://doi.org/10.3390/horticulturae5030052

Rosas-Burgos EC, Burgos-Hernandez A, Noguera-Artiaga L, Kacaniova M, Hernandez-Garcia F, Cardenas-Lopez JL, Carbonell-Barrachina AA (2017). Antimicrobial activity of pomegranate peel extracts as affected by cultivar. Journal of the Science of Food and Agriculture 97(3):802-810. https://doi.org/10.1002/jsfa.7799

Rowayshed G, Salama A, Abul-Fadl M, Akila-Hamza S, Mohamed EA (2013). Nutritional and chemical evaluation for pomegranate (Punica granatum L.) fruit peel and seeds powders by products. Middle East Journal of Applied Sciences 3(4):169-179.

Sadeghian A, Ghorbani A, Mohamadi-Nejad A, Rakhshandeh H (2011). Antimicrobial activity of aqueous and methanolic extracts of pomegranate fruit skin. Avicenna Journal of Phytomedicine 1(2):6773. https://doi.org/10.1078/0944-7113-00327

Sahafi SM, Goli SAH, Kadivar M, Varshosaz J, Shirvani A (2021). Pomegranate seed oil nanoemulsion enriched by $\alpha$ tocopherol; the effect of environmental stresses and long-term storage on its physicochemical properties and oxidation stability. Food Chemistry 345:128759. https://doi.org/10.1016/j.foodchem.2020.128759

Saleh H, Golian A, Kermanshahi H, Mirakzehi MT (2017). Effects of dietary $\alpha$-tocopherol acetate, pomegranate peel, and pomegranate peel extract on phenolic content, fatty acid composition, and meat quality of broiler chickens. Journal of Applied Animal Research 45(1):629-636. https://doi.org/10.1080/09712119.2016.1248841

Saleh H, Golian A, Kermanshahi H, Mirakzehi MT (2018). Antioxidant status and thigh meat quality of broiler chickens fed diet supplemented with $\alpha$-tocopherolacetate pomegranate pomace and pomegranate pomace extract. Italian Journal of Animal Science 17(2):386-395. https://doi.org/10.1080/1828051x.2017.1362966

Salgado L, Melgarejo P, Meseguer I, Sanchez M (2009). Antimicrobial activity of crude extracts from pomegranate (Punica granatum L.). Acta Hort 818:257-264. https://doi.org/10.17660/actahortic.2009.818.38

Sarkaki A, Yaghoub F, Hashemi Sh, Rafiei Rad M (2015). Pomegranate seed hydroalcoholic extract improves memory deficits in ovariectomized rats with permanent cerebral hypoperfusion/ischemia. Avicenna Journal of Phytomedicine 5(1):43-55.

Sartippour MR, Seeram NP, Rao JY, Moro A, Harris DM, Henning SM (2008). Ellagitannin-rich pomegranate extract inhibits angiogenesis in prostate cancer in vitro and in vivo. International Journal of Oncology 32:475-480. https://doi.org/10.3892/ijo.32.2.475 
Schubert SY, Lansky EP, Neeman I (1999). Antioxidant and eicosanoid enzyme inhibition properties of pomegranate seed oil and fermented juice flavonoids. Journal of Ethnopharmacology 66(1):11-17. https://doi.org/10.1016/s0378-8741(98)00222-0

Shafie MM, Rajabipour A, Castro-Garcia S, Jimenez-Jimenez F, Mobli H (2015). Effect of fruit properties on pomegranate bruising. International Journal of Food Properties 18(8):1837-1846. https://doi.org/10.1080/10942912.2014.948188

Shahid M, Shahid-ul-Islam Rather LJ, Manzoor N, Mohammad F (2019). Simultaneous shade development, antibacterial, and antifungal functionalization of wool using Punica granatum L. peel extract as a source of textile dye. Journal of Natural Fibers 16(4):555-566. https://doi.org/10.1080/15440478.2018.1428846

Shahrajabian MH, SunW, Soleymani A, Cheng Q (2020a). Traditional herbal medicines to overcome stress, anxiety and improve mental health in outbreaks of human coronaviruses. Phytotherapy Research 2020(1):1-11. https://doi.org/10.1002/ptr.6888

Shahrajabian MH, Sun W, Cheng Q (2020b). Exploring Artemisia annua L., artemisinin and its derivatives from traditional Chinese wonder medicinal science. Notulae Botanicae Horti Agrobotanici Cluj-Napoca 48(4):17191741. https://doi.org/10.15835/nbha48412002

Shahrajabian MH, Sun W, Cheng Q (2020c). Chemical components and pharmacological benefits of basil (Ocimum basilicum): a review. International Journal of Food Properties 23(1):1961-1970. https://doi.org/10.1080/10942912.2020.1828456

Shahrajabian MH, Sun W, Cheng Q(2020d). Traditional herbal medicine for the prevention and treatment of cold and flu in the autumn of 2020, overlapped with Covid-19. Natural Product Communications 15(8):1-10. https://doi.org/10.1177/1934578x20951431

Shahrajabian MH, Sun W, Cheng Q (2020e). Chinese star anise (Illicium verum) and pyrethrum (Chrysanthemum cinerariifolium) as natural alternatives for organic farming and health care- A review. Australian Journal of Crop Science 14(03):517-523. https://doi.org/10.21475/ajcs.20.14.03.p2209

Shahrajabian MH, Sun W, Chen Q (2021). Improving health benefits with considering traditional and modern health benefits of Peganum harmala. Clinical Phyto-science 7(1). https://doi.org/10.1186/s40816-021-00255-7

Shakhmatov EG, Makarova EN, Belyy VA (2019). Structural studies of biologically active pectin-containing polysaccharides of pomegranate Punica granatum. International Journal of Biological Macromolecules 122:29-36. https://doi.org/10.1016/j.ijbiomac.2018.10.146

Shams Ardekani MR, Hajimahmoodi M, Oveisi MR, Sadeghi N, Jannat B, Ranjbar AM, Gholam N, Moridi T (2011). Comparative antioxidant activity and total flavonoids content of Persian pomegranate (Punica granatum L.) cultivars. Iranian Journal of Pharmaceutical Research 10(3):519-524.

Sharma KK, Jadhav VT, Sharma J (2011). Present status of pomegranate bacterial blight caused by Xanthomonas axonopodis pv. punicae and its management. Acta Horticulturae 890:513-522. https://doi.org/10.17660/ActaHortic.2011.890.72

Sharma P, McClees S, Afaq F (2017). Pomegranate for prevention and treatment of cancer: an update. Molecules 22:177. https://doi.org/10.3390/molecules22010177

Sharma K, Akansha, Chauhan ES (2018). Comparative studies of proximate, mineral and phytochemical compositions of pomegranate (Punica granatum) in peel, seed and whole fruit powder. International Journal of Food Science and Nutrition 3(2):192-196.

Sheikh Asadi M, Mirghazanfari SM, Dadpay M, Nassireslami E (2018). Evaluation of wound healing activities of pomegranate (Punica granatum- Lythraceae) peel and pulp. Journal of Research in Medical and Dental Science 6(3):230-236.

Singh RP, ChidambaraMurthy KN, Jayaprakasha GK (2002). Studies on the antioxidant activity of pomegranate (Punica granatum) peel and seed extracts using in vitro models. Journal of Agricultural and Food Chemistry 50(1):8186. https://doi.org/10.1021/jf010865b

Smaoui S, Hlima HB, Mtibaa AC, Fourati M, Sellem I, Elhadef K, Ennouri K, Mellouli L (2019). Pomegranate peel as phenolic compounds source: Advanced analytical strategies and practical use in meat products. Meat Science 158:107914. https://doi.org/10.1016/j.meatsci.2019.107914

Smith AD, George NS, Cheung L, Bhagavathy GV, Luthria DL, JohnKM, Bhagwat AA (2020). Pomegranate peel extract reduced colonic damage and bacterial translocation in a mouse model of infectious colitis induced by Citrobacter rodentium. Nutrition Research 73:27-37. https://doi.org/10.1016/j.nutres.2019.11.001 
Sohrab G, Nasrollahzadeh J, Zand H, AmiriZ, Tohidi M, Kimiagar M (2014). Effects of pomegranate juice consumption on inflammatory markers in patients with type 2 diabetes: A randomized, placebo-controlled trial. Journal of Research in Medical Sciences 19:215-220. https://doi.org/10.1089/met.2017.0146

Soloklui AA, Ershadi A, Fallahi E (2012). Evaluation of cold hardiness in seven Iranian commercial pomegranate (Punica granatumL.) cultivars. HortScience 47:1821-1825. https://doi.org/10.21273/hortsci.47.12.1821

Sreekumar S, Sithul H, Muraleedharan P, Azeez JM, Sreeharshan S (2014). Pomegranate fruit as a rich source of biologically active compounds. BioMed Research International 686921:1-12. https://doi.org/10.1155/2014/686921

Stover ED, Mercure Eric W (2007). The pomegranate: a new look at the fruit of paradise. HortScience 42(5):1088-1092. https://doi.org/10.21273/hortsci.42.5.1088

Sturgeon SR, Ronnenberg AG (2010). Pomegranate and breast cancer: possible mechanisms of prevention. Nutrition Reviews 68(2):122-128. https://doi.org/10.1111/j.1753-4887.2009.00268.x

Song B, Li J, Li J (2016). Pomegranate peel extract polyphenols induced apoptosis in human hepatoma cells by mitochondrial pathway. Food and Chemical Toxicology 93:158-166. https://doi.org/10.1016/j.fct.2016.04.020

Sun W, Shahrajabian MH, Cheng Q (2021a). Fenugreek cultivation with emphasis on historical aspects and its uses in traditional medicine and modern pharmaceutical science. Mini Reviews in Medicinal Chemistry 21(6). https://doi.org/10.2174/1389557520666201127104907

Sun W, Shahrajabian MH, Cheng Q (2021b). Barberry (Berberis vulgaris), a medicinal fruit and food with traditional and modern pharmaceutical uses. Israel Journal of Plant Sciences 68(1-2):1-11. https://doi.org/10.1163/22238980-bja10019

Sun W, Shahrajabian MH, Cheng Q (2021c). Health benefits of wolfberry (Gou Qi Zi) on the basis of ancient Chinese herbalism and western modern medicine. Avicenna Journal of Phytomedicine 11(2):109-119.

Sundararajan A, Ganapathy R, Huan L, Dunlap JR, Webby RJ (2010). Influenza virus variation in susceptibility to inactivation by pomegranate polyphenols is determined by envelope glycoproteins. Antiviral Research 88(1):1-9. https://doi.org/10.1016/j.antiviral.2010.06.014

Surek E, Nilufer-Erdil D (2014). Changes in phenolics and antioxidant activity at each step of processing from pomegranate into nectar. International Journal of Food Sciences and Nutrition 65(2):194-202. https://doi.org/10.3109/09637486.2013.854745

Syed DN, Malik A, Hadi N, Sarfaraz S, Afaq F, Mukhtar H (2006). Photo-chemo preventive effect of pomegranate fruit extract on UVA-mediated activation on cellular pathways in normal human epidermal keratinocytes. Photochemistry and Photobiology 82:398-405. https://doi.org/10.1562/2005-06-23-ra-589

Taheri Rouhi SZ, SarkerMdMR, Rahmat A, Alkahtani SA, Othman F (2017). The effect of pomegranate fresh juice versus pomegranate seed powder on metabolic indices, lipid profile, inflammatory biomarkers, and the histopathology of pancreatic islets of Langerhans in streptozotocin-nicotinamide induced type 2 diabetic Sprague-Dawley rats. BMC Complementary and Alternative Medicine 17:156. https://doi.org/10.1186/s12906-017-1724-1

Tanaka T, Nonaka G-I, Nishioka I (1986). Tannins and related compounds. XL. Revision of the structures of punicalin and punicalagin, and isolation and characterization of 2-O-galloylpunicalin from the bark of Punica granatum L. Chemical and Pharmaceutical Bulletin 34(2):650-655. https://doi.org/10.1248/cpb.34.650

Tanveer A, Farooq U, Akram K, Haya Z, Shafi A, Nazar H, Ahmad Z (2015). Pomegranate extracts: A natural preventive measure against spoilage and pathogenic microorganisms. Food Reviews International 31(1):29-51. https://doi.org/10.1080/87559129.2014.961074

Tatari M, Jadidi E, Shahmansouri E (2020). Study of some physiological responses of different pomegranate (Punica Granatum L.) cultivars under drought stress to screen for drought tolerance. International Journal of Fruit Science. https://doi.org/10.1080/15538362.2020.1772177

Tavassoli-Hojjati S, Aliasghar E, Babaki FA, Emadi F, Parsa M, Tavajohi S, ... Ostad SN (2014). Pomegranate juice (Punica granatum): A new storage medium for avulsed teeth. Journal of Dentistry, Tehran University of Medical Sciences 11(2):225-232.

Topalovic A, Knezevic M, Gacnik S, Mikulic-Petkovsek M (2020). Detailed chemical composition of juice from autochthonous pomegranate genotypes (Punica granatum L.) grown in different locations in Montenegro. Food Chemistry 330:127261. https://doi.org/10.1016/j.foodchem.2020.127261

Tozzi F, Legua P, Martinez-Nicolas JJ, Nunez-GomezD, Giordani E, Melgarejo P (2020). Morphological and nutraceutical characterization of six pomegranate cultivars of global commercial interest. Scientia Horticulturae 272:109557. https://doi.org/10.1016/j.scienta.2020.109557 
Turk G, Sonmez M, Aydin M, Yuce A, Gur S, Yuksel M, Aksu EH, Aksoy H (2008). Effects of pomegranate juice consumption on sperm quality, spermatogenic cell density, antioxidant activity and testosterone level in male rats. Clinical Nutrition 27:289-296. https://doi.org/10.1016/j.clnu.2007.12.006

Turk, G, Sonmez M, Ceribasi AO, Yuce A, Atessahin A (2010). Attenuation of cyclosporine A-induced testicular and spermatozoal damages associated with oxidative stress by ellagic acid. International Immunopharmacology 10(2):177-182. https://doi.org/10.1016/j.intimp.2009.10.013

Turrini F, Zunin P, Catena S, Villa C, Alfei S, Boggia R (2019). Traditional or hydro-diffusion and gravity microwave coupled with ultrasound as green technologies for the valorization of pomegranate external peels. Food and Bioproducts Processing 117:30-37. https://doi.org/10.1016/j.fbp.2019.06.014

Usta C, Ozdemir S,Schiariti M, Puddu PE (2013). The pharmacological use of ellagic acid-rich pomegranate fruit. International Journal of Food Sciences and Nutrition 64(7):907-913. https://doi.org/10.3109/09637486.2013.798268

Valdes-Sustaita B, Estrada-Camarena E, Gonzalez-Trujano ME, Lopez-Rubalcava C (2021). Estrogen receptors- $\beta$ and serotonin mediate the antidepressant-like effect of an aqueous extract of pomegranate in ovariectomized rats. Neurochemistry International 142:104904. https://doi.org/10.1016/j.neuint.2020.104904

Verma N, Mohanty A, Lal A (2010). Pomegranate genetics resources and germplasm conservation: a review. Fruit, Vegetable and Cereal Science and Biotechnology 4(2):120-125.

Waly MI, Al-Rawahi AS, Al Riyami M, Al-kindi MA, Al-Issaei HK, Farooq SA, Al-Alawi A, Rahman MS (2014). Amelioration of azoxymethane induced carcinogenesis by reducing oxidative stress in rat colon by natural extracts. BMC Complementary and Alternative Medicine 14:60. https://doi.org/10.1186/1472-6882-14-60

Wang R-F, Xie W-D, Zhang Z (2004). Bioactive compounds from the seeds of Punica granatum (pomegranate). Journal of Natural Products 67(12):2096-2098. https://doi.org/10.1021/np0498051

Wang L, Ho J, Glackin C, Martins-Green M (2012). Specific pomegranate juice components as potential inhibitors of prostate cancer metastasis. Translational Oncology 5(5):344-355. https://doi.org/10.1593/tlo.12190

Wang P, Zhang Q, Hou H, Liu Z, Wang L, Rasekhmagham R, Kord-Varkaneh H, Santos HO, Yao G (2020). The effects of pomegranate supplementation on biomarkers of inflammation and endothelial dysfunction: A meta-analysis and systematic review. Complementary Therapies in Medicine 49:102358. https://doi.org/10.1016/j.ctim.2020.102358

Wang B, Guo C, Liu Y, Han G, Li Y, Zhang Y, Xu H, Chen D (2020). Novel nano-pomegranates based on astragalus polysaccharides for targeting ER $\alpha$-positive breast cancer and multidrug resistance. Drug Delivery 27(1):607-621. https://doi.org/10.1080/10717544.2020.1754529

Wu Y, Zhu C-P, Zhang Y, Li Y, Sun J-R (2019). Immunomodulatory and antioxidant effects of pomegranate peel polysaccharides on immunosuppressed mice. International Journal of Biological Macromolecules 137:504-511. https://doi.org/10.1016/j.ijbiomac.2019.06.139

Xu K, Zhu Z-Y, Kim C, Yamahara MS, Li Y (2009). Pomegranate flower ameliorates fatty liver in an animal model of type 2 diabetes and obesity. Journal of Ethnopharmacology 123(2):280-287. https://doi.org/10.1016/j.jep.2009.03.035

Xu J, Zhao Y, Aisa HA (2017). Anti-inflammatory effect of pomegranate flower in lipopolysaccharide (LPS)-stimulated RAW264.7 macrophages. Pharmaceutical Biology 55(1):2095-2101. https://doi.org/10.1080/13880209.2017.1357737

Yan L, Zhou X, Shi L, Shalimu D, Ma C, Liu Y (2017). Phenolic profiles and antioxidant activities of six Chinese pomegranate (Punica granatum L.) cultivars. International Journal of Food Properties 20(1):S94-S107. https://doi.org/10.1080/10942912.2017.1289960

Yang X, Nisar T, Hou Y, Gou X, Sun L, Guo Y (2018). Pomegranate peel pectin can be used as an effective emulsifier. Food Hydrocolloids 85:30-38. https://doi.org/10.1016/j.foodhyd.2018.06.042

Yayla M, Cetin D, Adali Y, Aksu Kilicle P, Toktay E (2018). Potential therapeutic effect of pomegranate seed oil on ovarian ischemia/reperfusion injury in rats. Iranian Journal of Basic Medical Sciences 21:1262-1268.

Yemis GP, Bach S, Delaquis P (2019). Antibacterial activity of polyphenol-rich pomegranate peel extract against Cronobacter sakazakii. International Journal of Food Properties 22(1):985-993. https://doi.org/10.1080/10942912.2019.1622564

Yisimayili Z, Abdulla R, Tian Q, Wang Y, Chen M, Sun Z, ... Huang C (2019). A comprehensive study of pomegranate flowers polyphenols and metabolites in rat biological samples by high-performance liquid chromatography 
quadrupole time-of-flight mass spectrometry. Journal of Chromatography A 1604:460472. https://doi.org/10.1016/j.chroma.2019.460472

Yogeeta S, Ragavender HRB, Devaki T (2007). Antihepatotoxic effect of Punica granatum. Acetone extract against isoniazid- and rifampicin-induced hepatotoxicity. Pharmaceutical Biology 45(8):631-637. https://doi.org/10.1080/13880200701538963

Yoshimura M, Watanabe Y, Kasai K, Yamakoshi J, Koga T (2005). Inhibitory effect of an ellagic acid-rich pomegranate extracts on tyrosinase activity and ultraviolet-induced pigmentation. Bioscience, Biotechnology and Biochemistry 69:2368-2373. https://doi.org/10.1271/bbb.69.2368

Zhang J, Zhan B, Yao X, Gao Y, Song J (1995). Antiviral activity of tannin from the pericarp of Punica granatum L. against genital Herpes virus in vitro. China Journal of Chinese Materia Medica 20(9):556-558. https://doi.org/10.4268/cjcmm20111432

Zhang Q, Jia D, Yao K (2007). Antiliperoxidant activity of pomegranate peel extracts on lard. Natural Product Research 21(3):211-216. https://doi.org/10.1080/14786410601130422

Zhang L, Fu Q, Zhang Y (2011). Composition of anthocyanins in pomegranate flowers and their antioxidant activity. Food Chemistry 127:1444-1449. https://doi.org/10.1016/j.foodchem.2011.01.077

Zhuang S, Li Y, Jia S, Hong H, Liu Y, Luo Y (2019). Effects of pomegranate peel extract on quality and microbiota composition of bighead carp (Aristichthys nobilis) fillets during chilled storage. Food Microbiology 82:445-454. https://doi.org/10.1016/j.fm.2019.03.019

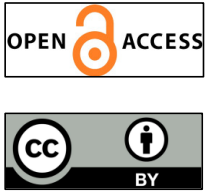

The journal offers free, immediate, and unrestricted access to peer-reviewed research and scholarly work. Users are allowed to read, download, copy, distribute, print, search, or link to the full texts of the articles, or use them for any other lawful purpose, without asking prior permission from the publisher or the author.

License - Articles published in Notulae Scientia Biologicae are Open-Access, distributed under the terms and conditions of the Creative Commons Attribution (CC BY 4.0) License.

(c) Articles by the authors; SHST, Cluj-Napoca, Romania. The journal allows the author(s) to hold the copyright/to retain publishing rights without restriction. 